University of Arkansas, Fayetteville

ScholarWorks@UARK

Education Reform Faculty and Graduate

Students Publications

Education Reform

6-26-2014

\title{
Finance for All: The Impact of Financial Literacy Training in Compulsory Secondary Education in Spain
}

\author{
Laura Hospido \\ Banco de España, Madrid \\ Ernesto Villanueva \\ Banco de España, Madrid \\ Gema Zamarro \\ University of Arkansas, Fayetteville, gzamarro@uark.edu
}

Follow this and additional works at: https://scholarworks.uark.edu/edrepub

Part of the Educational Assessment, Evaluation, and Research Commons, Educational Leadership Commons, and the Other Educational Administration and Supervision Commons

\section{Citation}

Hospido, L., Villanueva, E., \& Zamarro, G. (2014). Finance for All: The Impact of Financial Literacy Training in Compulsory Secondary Education in Spain. Education Reform Faculty and Graduate Students Publications. Retrieved from https://scholarworks.uark.edu/edrepub/111

This Article is brought to you for free and open access by the Education Reform at ScholarWorks@UARK. It has been accepted for inclusion in Education Reform Faculty and Graduate Students Publications by an authorized administrator of ScholarWorks@UARK. For more information, please contact scholar@uark.edu. 
FINANCE FOR ALL THE IMPACT

OF FINANCIAL ITERACY TRAINING IN COMPULSORY SECONDABY EDUCATION IN SPAIN

taura Hospido Exnesto Villanueva and Gema zamarro

Documentos de Trabajo N. 1502

banco mespaña

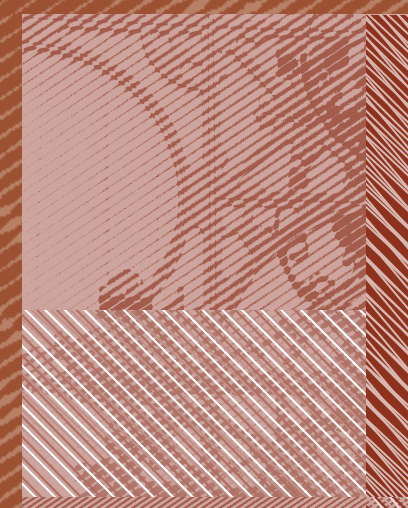


FINANCE FOR ALL: THE IMPACT OF FINANCIAL LITERACY TRAINING

IN COMPULSORY SECONDARY EDUCATION IN SPAIN 
FINANCE FOR ALL: THE IMPACT OF FINANCIAL LITERACY TRAINING IN COMPULSORY SECONDARY EDUCATION IN SPAIN ${ }^{* *}$

\author{
Laura Hospido \\ BANCO DE ESPAÑA AND IZA \\ Ernesto Villanueva \\ BANCO DE ESPAÑA
}

Gema Zamarro

UNIVERSITY OF ARKANSAS AND USC DORNSIFE CENTER FOR ECONOMIC AND SOCIAL RESEARCH

(*) We thank Olympia Bover, Annamaria Lusardi, Núria Rodríguez-Planas, Justin McCrary, an anonymous referee and seminar participants at Banco de España for comments and suggestions. We also thank Lucía Sánchez, Ismael Sanz and Francisco Javier García Crespo for their invaluable help with the data used in this article. The opinions and analyses are the responsibility of the authors and, therefore, do not necessarily coincide with those of the Banco de España or the Eurosystem. First draft: 26 June 2014 
The Working Paper Series seeks to disseminate original research in economics and finance. All papers have been anonymously refereed. By publishing these papers, the Banco de España aims to contribute to economic analysis and, in particular, to knowledge of the Spanish economy and its international environment.

The opinions and analyses in the Working Paper Series are the responsibility of the authors and, therefore, do not necessarily coincide with those of the Banco de España or the Eurosystem.

The Banco de España disseminates its main reports and most of its publications via the Internet at the following website: http://www.bde.es.

Reproduction for educational and non-commercial purposes is permitted provided that the source is acknowledged.

C BANCO DE ESPAÑA, Madrid, 2015

ISSN: 1579-8666 (on line) 


\section{Abstract}

We estimate the impact on objective measures of financial literacy of a 10-hour financial education program among 15-year-old students in compulsory secondary schooling. We use a matched sample of students and teachers in Madrid and two different estimation strategies. Firstly, we use reweighting estimators to compare the performance in a test of financial knowledge of students in treatment and control schools. In another specification, we use school fixed-effect estimates of the effect of the course on changes in scores in tests of financial knowledge. The program increased treated students' financial knowledge by between one-fourth and one-third of a standard deviation. We uncover heterogeneous effects, as students in private schools did not increase their knowledge much, possibly owing to a less intensive implementation of the program. Secondly, we analyze the bias that arises because the set of schools that participate in financial literacy programs is not random. Such selection bias is estimated as the pre-program performance in financial PISA of students in applicant schools relative to a nationally representative sample of schools. We then study whether estimators that condition on school and parental characteristics mitigate selection bias.

Keywords: financial education, impact evaluation, selection bias.

JEL classification: D14, I22. 


\section{Resumen}

En el marco del Programa «Finanzas Para Todos», el Banco de España y la Comisión Nacional del Mercado de Valores coordinaron en 2013 un curso de Educación Financiera en $3 .^{\circ}$ de la ESO. Este curso fue impartido por los profesores de más de doscientos centros, y sus contenidos versaban sobre el ahorro y la planificación financiera, las relaciones bancarias y el consumo inteligente. Este trabajo examina si este curso aumentó las competencias financieras de un grupo de alumnos de $3 .^{\circ}$ de la ESO en veintidós centros de Madrid. Para ello, en primer lugar, se comparan las competencias financieras de los alumnos que recibieron el curso con las de un grupo de estudiantes de $3 .^{\circ}$ de la ESO de dos centros que no impartieron la asignatura. En segundo lugar, se examina si los alumnos de $3 .^{\circ}$ de la ESO que cursaron la asignatura adquirieron mayores competencias financieras que los alumnos de $4 .^{\circ}$ de la ESO de esos mismos centros - que no la cursaron-. En ambos casos, el desempeño en pruebas de conocimiento financiero aumentó entre los alumnos a los que se impartió la asignatura en torno a un tercio de una desviación estándar. No obstante, el efecto varía entre centros y tipos de conocimiento, siendo mayor el efecto en el tema de relaciones bancarias y en los centros que aplicaron más intensivamente el temario. Finalmente, se comparan los conocimientos financieros de partida de los alumnos de los centros participantes con los de una muestra representativa de centros españoles para analizar la importancia de posibles sesgos de selección.

Palabras clave: educación financiera, evaluación de impacto, sesgo de selección.

Códigos JEL: D14, I22. 


\section{Introduction}

Today we live in a world of growing sophistication of financial products where the onus of a good financial situation and a good plan for the future is increasingly on citizens and less on governments. Given this trend, a growing concern exists regarding the level of preparedness of the general population to make sound financial decisions. This concern is motivated by research that has demonstrated that many families lack basic financial literacy. For example, Lusardi and Michell (2011), using data on adults 50 years and older from the United States survey "Health and Retirement Study" (HRS), find that only half of the sample group knew how to answer simple questions about interest rates and inflation correctly, and only one third was able to answer these questions and a question related to investment in the stock market correctly. Similar results were obtained using other samples for Americans of different ages and from different datasets, including young adults between 23 and 28 years of age using the 2007-2008 survey National Longitudinal Survey of Youth (NLSY) (Lusardi et al., 2010), adults 18 years or older from the Internet panel RAND American Life Panel (ALP) (Lusardi and Mitchell, 2009), high school students using data from JumpStart Coalition for Personal Financial Literacy and the National Council on Economic Education (Mandell 2008) and university students (Chen and Volpe, 1998 and Shim et al., 2010), among others. ${ }^{1}$ Similar results were also obtained in other countries such as Italy (Fornero and Monticone, 2011), Germany (Bucher-Koenen and Lusardi, 2011), the Netherlands (Van Rooij et. al, 2012 or Alessie et al., 2011), and France (Arrondel et. al., 2013).

As early as 2005, the OECD Recommendation specifically advised that "financial education should start at school. People should be educated about financial matters as early as possible in their lives" (OECD, 2005). ${ }^{2}$ Two main reasons support this recommendation. On the one hand, younger generations are likely to face ever-increasing complexity in financial products, services and markets; on the other, schools are well positioned to advance financial literacy among all demographic groups and reduce financial literacy gaps and inequalities.

In order to equip the general population with the necessary tools for making wise financial decisions, many educational systems have incorporated Financial Education (FE) as part of their curriculum in secondary education. For example, since 1957, various US states have been adopting mandates to include FE in the curriculum of high school students. As a result of these mandates, some states require FE as a mandatory subject in their schools. ${ }^{3}$ Another example is the FE program in the third year of Mandatory Secondary Education in Spain (the

\footnotetext{
${ }^{1}$ See Lusardi and Mitchell (2014) for a recent review of this literature.

${ }^{2}$ In its Recommendation on Principles and Good Practices for Financial Education and Awareness, the OECD defined financial education as "the process by which financial consumers/investors improve their understanding of financial products, concepts and risks and, through information, instruction and/or objective advice, develop the skills and confidence to become more aware of financial risks and opportunities, to make informed choices, to know where to go for help, and to take other effective actions to improve their financial well-being" .

${ }^{3}$ This is the case in 19 states, including Florida, Texas, Arizona, North Carolina and New Jersey, among others.
} 
Spanish equivalent of ninth grade in the US), jointly promoted by the Banco de España and the Spanish Stock Exchange Commission (BdE-CNMV Program), which has been offered for two academic years (2013 and 2014). The program is part of the broad "Finance for All" initiative, aimed at improving financial knowledge among the population. The general objective of the FE program was that students become sufficiently financially literate to take financial decisions and to ensure their financial well-being. In particular, it consists of a 10-hours course in FE with support from a website with guides and training materials. ${ }^{4}$

In this paper, we evaluate this intervention using data on twenty-two schools in the region of Madrid, using matched data on the teachers who gave the course and the family background and financial literacy scores of students. Our first estimation strategy compares the scores in a final exam on financial knowledge of those students that receive the FE course (the treatment) with the hypothetical outcome that these same students would have obtained if they had not received classes - who could have acquired financial knowledge through informal channels such as the family. The counterfactual performance in the final exam is inferred using a control group, composed of students in three schools in Madrid who did not receive classes but did conduct tests of financial knowledge. To ensure that the treatment and control groups are strictly comparable in observables, observations in the control group are re-weighted by assigning relatively more weight to those students whose characteristics are similar to those of the mean of the treated group. As the intervention was not randomized, we conduct two alternative tests of unconfoundedness by examining pre-program differential scores in financial knowledge between samples of treated students and an alternative control group. This second specification uses school-fixed effect estimates to obtain the impact of the program on the change in scores in financial literacy tests of students who took the course relative to those who did not.

We document three main findings. The first is that the program increased treated students' performance in overall financial literacy between one fourth and one third of a standard deviation, a surprisingly large result given the number of hours of the intervention. By examining the responses to particular questions of the exam we find that the impact of the program was not specially high among numerical questions, suggesting that the training provided in the course goes beyond applying basic numerical skills. Our evidence suggests an improvement in the score related to Banking relationships, while we can not find much evidence of learning about sustainable consumption. Finally, our tentative results suggest that there is substantial heterogeneity in the effect of the program across types of school. In particular, the impact of the program in private schools is at best negligible, another surprising finding given that those schools typically have students with a better background and more experienced teachers. Using survey data of the teachers of the course, we document that private schools made a much lighter use of the web-based facilities than non-private schools and took a lighter approach to teaching the course - for example, treated private schools did not evaluate students at the end of the course. The latter result highlights the relevance of obtaining information on program implementation.

\footnotetext{
${ }^{4}$ Section 2 contains more information about this program.
} 
In addition, we study the role of unobservable variables that prompt certain schools to decide to provide financial literacy courses (or selection in unobservable variables), an issue that is typically overlooked in studies on the impact of school-based financial literacy courses. Such selection is important in our setting because the control schools were not chosen randomly. However, even random assignment of treatment does not solve the problem that the existence of unobservable variables poses. In an experiment, each school that volunteers can be assigned to the treated group (schools that offer the course) or to the control group (schools that do not offer it), but a non-volunteer school cannot be forced to offer the course. If the treated schools differ from the rest of the population along unobservable variables, it is difficult to know if the estimated effect in an experiment can be extrapolated to other groups of the population.

Then, as a second contribution of this paper, we estimate the role of selection both in observable and in unobservable variables, by combining, on the one hand, the information available in the PISA 2012 financial literacy test for Spain with, on the other, the existence of the FE program offered one and two years later (2013 and 2014). We identify in PISA the schools that volunteered for both editions of the program (and that had not offered the subject before). In this sample, any difference in performance on PISA financial tests among students of the schools that volunteered for the program and the rest of the schools can be attributed solely to a selection bias. The wealth of PISA information allows us to (i) characterize the selection bias associated with volunteering to participate in a FE program and (ii) to study to what extent our estimation procedures can mitigate the role of unobservable variables.

We find a significant amount of selection bias, positive for boys and negative for girls. Comparing the characteristics of the schools that volunteer to participate in the program and those that do not, we see that both groups differ significantly in observable characteristics of the students such as the fact of having been held back a year, parents' employment status and the region where the school is located. In addition, the admissions criteria and the level of competition of schools providing financial literacy courses differ from those of the average school. Once we reweight the sample of students in schools that did not volunteer to take part in the program so that they have a similar rate of repetition, parents' employment status and regional distribution than schools that volunteered for the program, we can eliminate between $33 \%$ and $50 \%$ of the bias. When, in addition, students in schools with similar admissions criteria are compared, we are able to correct $65 \%$ of the bias. That evidence suggests that reweighting estimators like those we use in the first part of the paper deliver unbiased estimates of the impact of financial literacy courses on objective measures of financial knowledge.

Our results contribute to the growing literature assessing the relevance of financial literacy below 18 in two dimensions. Some experiments suggest that short financial literacy courses do increase financial knowledge. Walstad et al. (2010) show that a video on financial literacy to high school students increased scores in financial knowledge exams substantially. Bruhn et al. (2013) conduct a randomized experiment that randomly assigns a 78-hours course across Brazilian states. The course increase financial (and economic) knowledge in an objective test 
by a third of a standard deviation. On the other hand, Lührmann et al. (2012) show that a 90 minutes financial literacy course increased self-assessed financial knowledge as well as the ability to assess risks correctly of a sample of German teenagers between 14 and 16. However, those students did not perform well in other topics related to the role of advertisement. Bechetti et al. (2011) do not find any impact of financial literacy courses on financial knowledge in Italian high schools. Our results on the Madrid sample suggest that even in a relatively homogenous urban sample in the same city, results vary by type of school, possibly because implementation varies in dimensions that are hard to control. In addition, the existence of selection bias may provide an explanation for the diversity of results across studies, as different financial programs are directed to different groups of students. ${ }^{5}$

The rest of the paper is organized as follows. In Section 2 we describe the most important features of the FE program offered in Spanish schools. Section 3 presents our methodological approach, and Section 4 summarizes the main results of the evaluation. Section 5 provides the estimates of the selection bias. Finally, Section 6 concludes.

\section{The 2013 BdE-CNMV Program}

Between February and May of 2013, students of 275 Secondary Schools in Spain received classes of Financial Education under the National Financial Education Plan. The target population were students of the third year of high school, that would be completed between the ages of 15 and 16 -assuming normal progression through the educational system. The choice of the third year of high school (9th grade) is a balance between the objective of the program of reaching as many students as possible and the fact that the material was deemed appropriate for students in the later stages of compulsory schooling. The third year of high school is the last course in compulsory schooling with few, if any, elective courses. ${ }^{6}$

\subsection{The contents of the course}

The intervention consists on a set of teaching materials and resources which have been developed for a recommended 10 hours of lessons that were taught in those schools that voluntarily choose to participate. Such materials include the Student's Guide, which provides a set of contents on financial education tailored to the cognitive characteristics of students in the third year of high school. The Level I of the Guide focuses on contents related to financial security, the intelligent

\footnotetext{
${ }^{5}$ For example, the sample used by Lürhmann et al. (2012) is composed of students of low stream high schools in Germany, leaving out other tracks. The samples in Bruhn et al. (2013) or Walstad et al. (2010) contain public high schools that volunteered for the program.

${ }^{6}$ Fourth year of high school is the last year of compulsory schooling, but it contains already many electives, and it was considered that many schools would give the material in one of those electives, thus restricting the outreach of the program. Students in Spain must complete 6 grades of primary schooling, starting at 6 and finishing at 12. After that age, students must compulsorily attend lower secondary education for four extra years. At the time of the program, all those degrees were common and compulsory for all students.
} 
consumption, saving, personal budgeting, cash, accounts and banking relationships, cards and personal data protection (see Appendix A for a brief description of each of those topics). The Level II contains advanced materials on different means of payment and savings products and financing. The implementation of the program in 2013 focused on Level I only. The Teacher's Guide contains the same materials worked in the Student Guide, together with the solutions to the proposed activities. In addition, this Guide includes a Financial Trivial and a Game of the Goose with general questions about the contents. Finally, both teachers and students have an online support through the website Gepeese (http://www.finanzasparatodos.es/gepeese/) offering practical exercises, activities, games, and additional resources to enhance the development of the program.

The program aimed at increasing financial knowledge among the population of students and facilitating taking better financial decisions later in life. There are at least three ways through which financial education can facilitate this aim. The first is by raising awareness about the future and avoiding present bias. Consumers may have hyperbolic preferences so that they discount consumption choices between today and the near future (say, three months from now) at a rate that exceeds the rate they apply to future choices (say, between three and six months from now). Financial education makes individuals aware about the future consequences of current actions, leading students to apply similar discount rates to present and future choices -see Lührmann et al. (2014) or Alan and Ertac (2014). That channel emphasizes that education shapes individual's preferences. A second channel takes preferences as primitives and stresses framing problems in financial choices. Ambuehl et al. (2014) find that individuals choices between two allocations vary depending on how the choices are presented. The same individual chooses one allocation if the choices are presented as given amount of dollars in two moments in time but a different one if the same choices are presented in terms of the take up of a financial product that achieves those same amounts. Financial education helps individuals in making choices consistent when presented in alternative forms. Finally, some scholars have argued that a lack of financial knowledge simply reflects a lack of numeracy skills. Financial education may then help individuals by putting numerical skills into practice.

It is likely that all channels operate in the case of the BdE-CNMV program. The contents of some chapters provide basic information about basic financial products while stressing the consequences of current saving behavior. Special attention is given to the way of managing a stream of revenues and expenses to meet a future target (for example, purchasing a bicycle). Arguably, those topics try to accomplish that students are able to reconcile consumption choices and saving vehicles -similar to the financial competence concept that Ambuehl et al. (2014) suggest. The program also emphasizes the importance of saving or the advantages of sustainable consumption. The latter topic arguably tries to shape preferences. We look at the responses to different questions to get some insights on which channels may have been most relevant. 


\subsubsection{Implementation}

After an advertising campaign during the academic course 2011-2012, teachers from 275 schools requested access to the materials in 2012. Access to the materials was granted to all solicitants by sending them a login and a password. Despite the recommendation of teaching the material among 15-16 years of age, teachers could choose the specific grade and course where those materials be taught. ${ }^{7}$ According to a survey passed to all teachers giving the course, the material was taught during regular school hours. Given the interdisciplinary nature of the course, the material was given in different classes. $25 \%$ of teachers reported having given the material as part of the Mathematics class, while $20 \%$ gave it as part of the regular Social Sciences and Geography class. In other cases, the material was taught in courses without standardized content, such as the weekly tutorial time $(17 \%)$ or in courses tailored to students who choose not to attend the Religion class (6\%). The median number of hours taught per teacher was 10 . Furthermore, $46 \%$ of teachers declaring having complemented the classes with home assignments (mostly applications of the materials taught in real-life examples). Those teachers estimate that the average time required to complete those assignments was about 1 hour and a half.

Teachers who were granted access to the materials received a diploma that could be used to obtain future promotions. Schools also received the certification of participation in the program. There was no specific training for teachers (on top of the material provided). Survey information suggests that $40 \%$ of teachers had a specialization in Social Sciences or Economics, and that another $33 \%$ were specialized in Maths or Physics. ${ }^{8}$

\subsection{Evaluation in 2012-2013}

The impact of the financial literacy program was assessed by conducting two tests in all participant schools in the region of Madrid and six schools in Andalusia. One test was conducted in February 2013 - prior to the initial start of the program, called pre-test- and the second one was conducted after the full development of Level I in May 2013 -the post-test. ${ }^{9}$ Schools in the evaluation sample gave the material in the third year of high school only. In addition, students in the fourth year of high school went through the same set of financial literacy tests but were not taught the financial literacy material.

The results of the pre- and the post- test had not curricular consequences. Hence, students

\footnotetext{
${ }^{7}$ In the particular case of the evaluation sample, treated students were all in third grade.

${ }^{8}$ Overall, about $70 \%$ of participants had background on Social Science (including Economics) or Mathematics: $17 \%$ of teachers were economists, $33 \%$ were specialized in Mathematics or Physics and $22 \%$ had an specialization in Geography and Social Sciences.

${ }^{9}$ To ensure comparability of results between the pre-test and post-test, two parallel forms (A and B) were constructed. In the pre-test each form consists of 30 items: 20 are common, and 10 items are specific to each form. These specific items will be applied in the cross post-test; that is, those students who made the A form in the pre-test make the specific items in the post-test B (and vice versa). The two tests A and B post-test also have 20 common items, different from the pre-test. All examinations were carried out by computer, supervised by the staff of the company that made the fieldwork (FESE foundation).
} 
had the same incentive to perform well as they would have in a PISA test. There was however an incentive to learn the material because $60 \%$ of teachers in the evaluation sample included financial literacy contents as a part of the compulsory curriculum (Social Science or Maths).

\subsubsection{The control sample}

Prior to the implementation of the program, two control schools in the region of Madrid were approached and convinced to implement a pre-test and post-test to students in the third year of high school at the same time than the treatment group -however, those schools did not offer any training on financial literacy. Both schools was chosen because they had collaborated with the fieldwork company in the past and had shown some interest in the financial literacy program. A third school contained both a treated and a control group in the third year of high school. The choice of the control group is not random.

The main evaluation is made by comparing the group in third year of high school that received the class (or "treatment" group) and the group of students in control schools that also did the exams but did not participate in the program (called the "control" sample). We make limited use of the group of students in fourth year of high school in treated schools as an additional control group. It is not clear to what extent not participating in the program made students less motivated to perform well in the test than participant students. We can only get indirect information about their motivation by examining how achievement in the pre-test varies with participation in the program. Our estimates in Table 3 (discussed below) do not suggest a lower performance among control students, after controlling for parental characteristics and school type.

\subsubsection{The evaluation sample}

The main evaluation sample uses students in Madrid. The estimation sample that we use includes 1,223 students of 3rd grade in 22 schools of Madrid (981 treated and 242 controls). Table 1 , columns 1 and 2, shows descriptive statistics for the treated and control groups, respectively. The proportion of girls is higher among the treated students, whereas the incidence of grade repetition and the proportion of private schools is higher among the controls. Parents are more educated and skilled in the control group than in the treated group, while the proportion of those who work is higher for the treated. We discuss those differences below.

\subsubsection{Evaluation tools}

We use four evaluation tools. The first tool is the score in each of the aforementioned exams made by students in the evaluation and the control samples. The second tool were on-line surveys that the families of the students in Madrid had to fill. The third tool were on-line questionnaires filled by the principals of the treated and control schools. Finally, the fourth tool is a survey made to the teachers who taught the program, both in Madrid and elsewhere. 
That information provides details on how the program was implemented. The four tools permit us to build a matched teacher-student sample.

Standardized tests Each test contained 30 different questions on three main topics: saving and financial planning (9 questions in one of the two post-tests), money and banking (18 questions in that post-test) and sustainable consumption (3 questions). The questions were designed by an interdisciplinary team of Educational Science experts, and a pilot study on their reliability was conducted in a limited number of schools prior to the test. All questions were multiple choice, giving four different possibilities of which only one was correct. Importantly, each student faced different questions in the pre- and the post- test. ${ }^{10}$

The test was designed to determine if students had acquired certain competences in the three domains mentioned above. Questions on "Savings and Financial Planning" presented students with a fictional budget (including expected incomes and expenses) and asked about the soundness of the financial situation of that family or about the feasibility of reaching certain saving targets in a given period. Questions on "Banking relationships" asked about identifying the characteristics of saving and checking accounts, or about the meaning of key components of a bank statement. Alternatively, students were asked to compute the remaining balance in an account at a future date given an expected flow of revenues and expenses and an initial balance. Finally, questions on "Sustainable Consumption" posed a fictional situation where a given need could be satisfied in alternative ways. The students were to identify which form was more environmentally friendly or healthier than the rest (see Appendix B for a brief description of the questions in the test).

Parental questionnaire In March 2013 parents were sent an on-line questionnaire, asking 20 questions about their education, occupation as well as indicators of their socio-economic background (number of cars, televisions, availability of room and table to study, etc.). We use that information to elaborate a weighting scheme of the sample of non-participant students so that their average characteristics are comparable to those of treated students. The overall response rate of parents was high (83\%) and we only use students for whom we have information about parental background.

School-level information In June 2013, the principals of the treated and control schools filled an on-line questionnaire about basic characteristics of the school. We use the information about school type as a control variable in the analysis (namely, whether the school is private or not).

Teacher-level information In addition, in June 2013, once the course had been delivered, all teachers involved were asked to fill an on-line survey about their own background and about

\footnotetext{
${ }^{10}$ See Bruhn et al. (2013) on the potential problems associated to posing twice the same questions.
} 
the details about the implementation. Among other items, the questionnaire enquired about the course where the material was given, the exact number of hours taught, the parts of the material covered and their assessment about the usefulness of the program. We make use of this material in Table 2. $80 \%$ of students took the course from a teacher that used the webpage. The degree of completion of the syllabus was very high, as $90 \%$ of the students were lectured on at least 7 of the nine topics. In the evaluation sample, $67 \%$ of students took financial literacy as part of a math course, $24 \%$ in a social science course and the rest in other courses. However, and possibly due to constraints in increasing the teaching load, the course was typically taught by 2 or more teachers, so $50 \%$ of students in the evaluation sample had a teacher with a social science background. Finally, the teachers reported a high degree of satisfaction with the program. ${ }^{11}$

\section{Estimating the Impact of the Program}

We compare the score in the final exam on financial knowledge of students in the treatment group to a predicted value of the score that those students would have obtained if they had not received classes - assuming that in that case they would have acquired financial knowledge through other subjects or other informal channels such as family.

\subsection{Reweighting estimates}

The counterfactual performance in the test in the absence of the treatment is inferred using the grades in the post-test of the control group, that is composed of students who did not receive a financial literacy course but completed both the pre- and the post-test. Generating a counterfactual grade in the post-test for a student who had received the course on the basis of the performance in the post-test of similar students requires that the characteristics of the treatment and control groups are similar in their initial financial knowledge as well as their family environment.

As mentioned above, students in the treatment and control groups belonged to different schools, and had different background characteristics. Hence, we use the rich contextual observable information at our disposal about students, their parents and schools to reweight the sample of controls in a manner that can provide a counterfactual to the grades of the treatment group.

Formally, we can define an indicator of belonging to the treated group as $D_{i}=1$, and $D_{i}=0$ if student $i$ belongs to the control group. We denote as $Y_{i}$ the score on the final exam, and $X_{i}$ a vector $K \times 1$ of regressors (including a constant term). The score in terms of potential outcomes can be expressed: $Y_{i}=D_{i} Y_{i}^{1}+\left(1-D_{i}\right) Y_{i}^{0}$, where $Y_{i}^{1}$ is the result that student $i$ would have obtained if she had received the course, and $Y_{i}^{0}$ if had not taken financial education classes.

The average effect we are interested in estimating to assess the impact of the program is: $E\left[Y_{i}^{1} \mid D_{i}=1\right]-E\left[Y_{i}^{0} \mid D_{i}=1\right]$, where the second term is unobservable and it must be estimated.

\footnotetext{
${ }^{11}$ Table 2 gives details on implementation of the program for the evaluation sample.
} 
Under the standard assumptions of conditional independence:

$$
\left(Y_{i}^{1}, Y_{i}^{0}\right) \perp D_{i} \mid X_{i}
$$

and common support,

$$
0<e\left(X_{i}\right)<1
$$

where $e\left(X_{i}\right)=\operatorname{Pr}\left(D_{i}=1 \mid X_{i}\right)$, we have that:

$$
E\left[Y_{i}^{0} \mid D_{i}=1\right]=E\left[\omega\left(X_{i}\right) Y_{i} \mid D_{i}=0\right],
$$

with $\omega\left(X_{i}\right)=\frac{1-\pi}{\pi} \times \frac{e\left(X_{i}\right)}{1-e\left(X_{i}\right)}$, and $\pi=\operatorname{Pr}\left(D_{i}=1\right)$. That is, we can impute the counterfactual distribution of the scores of the treated group if they had experienced no treatment by reweighting the sample of controls. The weights $\omega\left(X_{i}\right)$ increase the relevance in the control sample of the observations that are very similar to treated students, where similarity is defined by the predicted probability of "participation" in a logit that explains participation with some covariates $X_{i} \cdot{ }^{12}$ For our analysis we use the inverse probability weighting estimator. ${ }^{13}$ This procedure aims to obtain estimates of the average treatment effect for the treated (ATT), that is, the average effect for those in schools that teach the course. ${ }^{14}$

Given a set of covariates $X$, assumption (2) is testable, by comparing the distributions of the probability of participation in the program between the treatment group and the controls. ${ }^{15}$ Moreover, the existence of biases in the estimated impact of the program depends critically on assumption (1). In principle, those schools that voluntarily chose to participate in the financial education program may have done this for reasons such as a special interest of parents or teachers, or a special concern for financial performance of students in the center. If these variables are correlated with the distribution of potential outcomes, our estimate of the impact of the intervention on test scores would be biased. Section 5 uses the PISA exam on financial knowledge to detect selection bias among schools that volunteered for the program.

\subsection{School fixed-effects estimates}

The second parameter we estimate is the difference between the (observed) change in grades between the pre- and the post test among students who received the course and the (unobserved)

\footnotetext{
${ }^{12}$ Given the variety of available characteristics, and the limited size of the sample, we compare "treated" students with "control" students using a continuous variable of susceptibility to treatment (propensity score). An alternative, feasible only on the basis of more data, would be to compare each "treated" student with students of the control group with exactly the same observed characteristics. However, we do not expect this second option to produce very different results given that Rosenbaum and Rubin (1983) demonstrated that the two methods are equivalent under the assumption that selection is only due to observables.

${ }^{13}$ We implement the estimator by running GLS regressions of grades on treatment, where each observation is weighted by $\omega\left(X_{i}\right)$. As a robustness check, we include the covariates $X_{i}$ also in the regression.

${ }^{14}$ See Hirano et al. (2003) or Busso et al. (2013) for methodological details.

${ }^{15}$ In Section 4, we provide evidence-based graphics on the existence of common support in the data.
} 
change in grades that these students would have experienced if they had not received the course. That is,

$$
\Delta=E\left[Y_{i}^{1}(1)-Y_{i}^{1}(0) \mid D_{i}=1\right]-E\left[Y_{i}^{0}(1)-Y_{i}^{0}(0) \mid D_{i}=1\right] .
$$

$Y_{i}^{1}(1)\left(Y_{i}^{1}(0)\right)$ is the observed performance in the post-test (pre-test) of students who received the material. $Y_{i}^{0}(1)$ is the unobserved performance in the post-test of those students had they not taken the course. We estimate $E\left[Y_{i}^{0}(1)-Y_{i}^{0}(0) \mid D_{i}=1\right]$ using students in the treated schools who were also tested but who did not receive the course. Those students were all in fourth year of high school (tenth grade). Hence, we assume

$$
E\left[Y_{i}^{0}(1)-Y_{i}^{0}(0) \mid D_{i}=1, X\right]=E\left[Y_{i}^{0}(1)-Y_{i}^{0}(0) \mid D_{i}=0, X\right] .
$$

Assumption (3) implies that the evolution of scores in financial knowledge among fourthgrade students represents an unbiased estimate of what the evolution of financial knowledge among third grade students would have been in the absence of the course. In other terms, assumption (3) implies that financial literacy is acquired through informal means at the same pace at age 15 or at age $16 .{ }^{16}$ Secondly, assumption (3) rules out spillover effects within the school. For example, it would fail if teachers who gave the financial literacy course in the third year of high school used parts of the material in their fourth-year classes. On the other hand, as the parameter $\Delta$ is estimated within the set of schools that volunteered for the program, assumption (3) holds even if there are time invariant characteristics that lead centers to teach financial literacy.

The impact of the program is identified in this case by the coefficient $d$ in a model with school-level fixed effects

$$
\Delta Y_{s, i}=Y_{s, i}(1)-Y_{s, i}(0)=\alpha_{s}+d \times 1\left(D_{i, s}=1\right)+\Delta \varepsilon_{s, i}
$$

$\Delta Y_{s, i}$ is the observed change in grades between the pre- and the post-test of student $i$ in school $s$, and $1\left(D_{i, s}=1\right)$ is an indicator of having received the financial literacy course. Finally, $\alpha_{s}$ is a school-level fixed effect. $d$ is the estimate of $\Delta$.

\section{Results}

Before discussing the results, we describe the outcome of interest $Y_{i}$. We use various measures of performance in the test. The first is a PISA-like normalized score in a scale from 0 to 10. That strategy gives a different weight to each question in the pre- and post- test according to the fraction of students who guessed the answer correctly. Our second measure is, simply, the sum of correct answers in the 30-question test, divided by 3 . We term that outcome the average of correct answers.

\footnotetext{
${ }^{16}$ We provide below some supportive evidence in favor of that assumption by comparing the grade growth of control students in treated schools (who are all in 4th year of high school) and the grade growth of control students in control schools (3rd year of high school).
} 


\subsection{Are students who received financial literacy courses similar to those in the control group?}

Students who received the financial literacy course are different in important respects from those who serve as a control. As shown in Table 1, relative to students who took the course in financial literacy, controls came disproportionally from private schools, were less likely to be girls - mostly due to the presence of three classes from a single-sex school - were 8 points more likely to have mothers with a college degree and 8 points more likely to have mothers working in a high skill occupation. On the other hand, even though average differences in pre-test scores were not substantial between treatment and controls, there were statistically significant differences in the pre-test within students in private schools. An important difference is that $73 \%$ students come from schools publicly funded but privately owned (concerted schools). Conversely, students in the control sample are either from a school publicly funded and run by the state or from a private school. In the analysis below we pool all publicly funded schools into a single category. ${ }^{17}$

Propensity score We estimate the predicted probability of program participation as a function of contextual information on students, parents, and type of school -the propensity score $e(X)$. The set of determinants included in $X$ was chosen according to the differences in mean covariates documented in Table 1. We include indicators of female student, of whether the student had repeated a grade and the initial grade in the pre-test as well as the type of school. Regarding parental variables, we included only those of the mother, leaving out those of the father. Such omission leads to a more parsimonious specification. ${ }^{18}$ We then augment the basic Logit model by including additional variables or interactions that were statistically different from zero according to a two-sided t-test, finally reaching the specification in Table 3. The estimates of the propensity score confirm the results of Table 1. Treatment and control students in non-private schools performed similarly in the pre-tests (the main term "Score in the pre-test" does not predict participation). However the interaction of "score in the pre-test" and private school is negative, suggesting that treated students in private schools performed worse than their counterparts in the control school. That evidence is not consistent with the hypothesis that students in control schools were less motivated to do the test. As for the rest of covariates, and compared to control students, the mothers of treated ones were more likely to be currently working and to report having a mid-skill occupation.

\footnotetext{
${ }^{17}$ We have explored if students in concerted schools had a different performance in financial literacy tests by regressing the treated students' grades in the pre-test on parental background and type of school dummies. Controlling for parental background, the dummy "concerted school" was not statistically significant. That finding supports our assumption that, conditional on parental background, students in public and concerted schools performed similarly.

${ }^{18}$ In addition, variables excluded from the propensity score allow an assessment of whether the reweighting of the sample on the basis of the information on the mother achieves a balanced sample in terms of characteristics we do not explicit condition upon.
} 
Differences in observables and comparability across samples The third column of Table 1 presents the means of the control sample, once that sample is reweighted by $\omega(X)=$ $\frac{1-\pi}{\pi} \frac{e(X)}{1-e(X)}$. The differences in the characteristics listed in the first panel of Table 1 shown in Columns 1 (treated group) and 3 (reweighted controls) are not statistically different from each other. An exception is the share of mothers with a college degree, slightly higher in the control sample than in the reweighted sample. More importantly, the sample is also similar along dimensions that we do not explicitly include in the propensity score - variables such as the education or occupation of the father. Again, the only exception is the share of parents in middle-skilled occupations, higher in the treatment than in the control sample.

Figure 1 presents a visual comparison of how similar the control sample and the treatment samples are. Firstly, the support of the values of the propensity score of treated students (the triangles at the top) and that of the control (the circles at the bottom) both range from about 0.29 to 0.97 . Secondly, there is accumulation of the value of the propensity score of controls (density in dotted line) and treatments (density in solid line) above 50 percentage points. Overall, the assumption of common support seems to hold in our sample. We do not trim the sample of treatments or controls.

\subsection{Are students who received financial literacy different along unobserved dimensions? Assessing unconfoundedness}

In the absence of a randomized experiment, a possible concern is that students in treated and control schools differ along unobserved variables. We follow Imbens (2014) and examine if students in the third year of high school in schools that volunteered for the program differed from those in control schools in variables that are related to the outcome of interest but cannot have been affected by the treatment. In particular, Imbens (2014) proposes examining lagged values of the outcome evaluated before treatment, a variable that in our case would correspond to the grades of the pre-test. The results are shown in Table 4. In none of the cases the performance in the pre-test varies with treatment.

\subsection{Differences in outcomes}

\subsubsection{Changes in the mean and in the distribution of financial literacy scores}

The estimated effect of the program is reported in the Panel A of Table 5 (also in the first row of Panel B in Table 1). The treated group attained an overall score of 5.24, while that of the (reweighted) control attained 4.88. The 0.36 difference is the impact of the program, that amounts to 0.28 of one standard deviation $\left(=\frac{0.36}{1.27}\right)$. The standard error accounts for arbitrary correlation at the school level and is 0.21 , so the estimate is only statistically significant at the 10 percent confidence level. The effect is remarkably similar -but much more precise- when we 
hold constant all the variables included in the logit model used to obtain the weights (column 2). The point estimate is similar when we use a nearest neighbor PS matching estimator (column $3) \cdot{ }^{19}$

Figures 2 and 3 investigate how financial literacy changes the whole distribution of scores in the post-test. For each possible value of the score $x$ in the $\mathrm{X}$ axis, the $\mathrm{Y}$ axis shows the proportion of the sample that obtaining a grade below $x$ (i.e., the conditional distribution function of grades). We present three cdf's: the cdf of scores among the treated group of students (solid line), the actual distribution of scores among controls (dashed line) and the reweighted distribution of controls (dotted line). Figure 2 reports the corresponding distributions of pre-test scores with no noticeable difference among the three lines.

Figure 3 shows the distributions of post-test scores. Now we obtain that, for each possible value of the score in the x-axis, there is a lower fraction of students below that score among the treated sample (solid line) than among the reweighted control sample (dotted line). As the reweighted sample is, under our assumptions, the distribution of the scores that treated students would have achieved in the absence of the program, the patterns in Figure 3 suggest an overall increase in the distribution of financial knowledge.

\subsubsection{Financial literacy vs numeracy}

The materials of the course presented the student with the fictional balance of a household or, alternatively, with alternative bank accounts with different fees and commissions. Contents also included qualitative answers teaching which consumption strategies were more appropriate for maintaining a sustainable level of consumption. Hence, a valid question is: did the program increased financial literacy or it just provide further training in applied math? We cast some light on the issue by examining the impact of the program on the score in questions with differential arithmetic content.

Namely, we classified the 30 questions in the final exam on financial knowledge into "arithmetic" and "non-arithmetic" ones (see Appendix B for details). The first set is composed by questions that require either a numerical computation or, alternatively, assessing a situation based on a numerical score. Approximately, one third of the questions were numeric according to that definition. Finally, we construct separate grades on a 0 to 10 scale for the arithmetic and the non-arithmetic parts.

Table 6 shows the average grade in the numerical and non-numerical parts among treated and (reweighted) controls. The average of overall correct answers in the treated sample is 0.40 points higher than in the (reweighted) control. On the other hand, the average of correct answers in the numerical part of the exam is 0.24 points higher among the treated group, and the result does not vary much when we include the covariates in the propensity score in the regression. However, both estimates are not statistically different from each other. In any case, the results in Table 6 do not support the hypothesis that the whole impact of the program is working through a differential performance in the numerical part.

\footnotetext{
${ }^{19}$ We do not present OLS estimates. The magnitude is qualitatively similar to that of the reweighting estimator, but it varies substantially depending on whether or not we control for further covatiates.
} 


\subsubsection{Differences by topic}

We also examine to what extent the program increased different aspects of financial knowledge. The exam covered topics on three main areas: saving and planning, banking relationships and responsible consumption (see Appendix B). Hence, we classified each question in those three areas and computed the average of correct answers for each part. Using that measure as the dependent variable, we computed differences in the average grade for each part between treatment and the (weighted) control sample -with and without controlling for further covariates.

The results are shown in Table 6. We find that knowledge of topics related to banking relationships and of saving and financial planning increased on average after the course. However, the point estimate in the sustainable consumption part is negative, small and not statistically different from zero. One possible explanation is that, unlike the contents of banking relations or saving and financial planning, identifying sustainable consumption in particular situations lacks a solid theoretical basis.

\subsubsection{Heterogeneity in implementation? Differences by school type}

Next, we examine students' performance in the post-test by type of school -private or not. The rationale of such distinction lies in the markedly different set of characteristics of the parents whose children attend private schools, as they are more educated and work in jobs with a higher skill content than the rest. The comparison is made by means of the following linear regression:

$$
E\left[Y_{i} \mid D_{i}=1, \text { private }_{i}=1\right]=\gamma_{0}+\gamma_{1} D_{i}+\gamma_{2} \text { private }_{i}+\gamma_{3} \text { private }_{i} * D_{i}
$$

where each observation of controls is weighted by $\omega\left(X_{i}\right)=\frac{1-\pi}{\pi} \times \frac{e\left(X_{i}\right)}{1-e\left(X_{i}\right)}$ while treated students has a weight of $1 . X_{i}$ contains the set of controls displayed in Table 3 . In a specification without covariates, $\gamma_{3}$ measures the the difference in scores in the final exam between treated and controls within the set of private school students. The comparison is appropriate if the covariates of private school students in the control and treated schools are comparable to each other. We compare those characteristics using the propensity score. The top panel of Figure 4 provides some evidence by plotting the distributions of the propensity score of treated and control students in private schools. Both distributions overlap and share a common support -although the overlap in particular covariates cannot be complete, because the control private school contains no females. Similarly, the overlap of the distribution of covariates in non-private schools among treated and controls is similar as well. The visual evidence in Figure 4 supports the use of a regression model with interactions.

Table 7 compares the average performance in the post test of treated students in private schools to students in control private schools. The results point at negligible effects of the program on those private schools. In a scale from 0 to 10 , the average score in the post-test in treated private schools was -0.13 points lower than in the control private school. On the other hand, the average of correct answers in post-score grades was 0.54 points higher in the treated 
non-private schools than in the control non-private schools. Importantly, within each type of school, once we reweight the sample by the propensity score, there were little differences in the mean pre-test scores among those groups.

Those results are surprising at face value, because the characteristics of private school students lead one to expect a substantial impact of the program. Parents of private school students have higher schooling levels and work in more skilled jobs. Furthermore, the proportion of students who fail to pass a grade and must take it twice is also lower in private schools. One possible explanation for the lack of an impact is that the effect of financial training on objective measures of knowledge can be specially large among students with weaker parental background. Schools could be very effective in providing financial knowledge within the set of students whose parents have lower schooling, for example. However, using a sample of students in non-private schools, we could not find a differential impact of the course by the schooling or occupation of the mother. ${ }^{20}$

The information on implementation of the program by school type provides some insights on the sources of the differences by school type. Without attaching any causal interpretation, we compare details on program implementation in private and non-private schools in Table 2. Firstly, we do not find large differences in the degree of completion of the syllabus as teachers in the treated private schools were equally likely to have covered all the material than their counterparts in non-private ones. Furthermore, teachers in private schools have more years of overall experience.

However, the implementation of the program differed between private and non-private schools. Teachers in private institutions reported having used the Web facilities less than their colleagues in non-private institutions. Only $63 \%$ of students in private schools took the course with a teacher who used the program's web page, compared to $85 \%$ in non-private schools. Secondly, none of the teachers in the private schools that participated in the program reported having made an independent evaluation of the financial literacy of the students after the course. Conversely, teachers report that $55 \%$ of students in non-private schools took an evaluation on the contents of the course that was independent of the pre- and post- test. A possible explanation is that, according to the teacher's survey, while $18 \%$ of non-private school students were given the material in classes with no standardized curriculum (tutorials or alternative to Religion), the corresponding number in private schools was $45 \%$.

\footnotetext{
${ }^{20}$ We used the sample of non-private schools to estimate models where treatment is interacted with dummies for whether or not the mother had college (either 4- or 2-year). The estimation uses OLS and we weight control students by $\frac{1-\pi}{\pi} \frac{e\left(X_{i}\right)}{1-e\left(X_{i}\right)}$. In a different specification, we interacted treatment with dummies for whether or not the mother works or has worked in a high skill occupation (managers, scientists or professionals). The sign and magnitude of the interactions do not give strong evidence of differential impacts by the characteristics of the mother. The results are not shown, but available upon request.
} 


\subsection{Robustness: student fixed effects estimates in treated schools}

This section experiments using an alternative estimation strategy. In six treated schools, one class in 10th grade in the schools that participated in the program did not take the course, but students were nonetheless tested on their knowledge about financial literacy in February and May 2013. The tests were the same for students in their fourth year of high school (10th grade) and in the third year (9th grade). Under the identifying assumption that, in the absence of the program, the change in the financial score would be the same among students in the third year and in the fourth year, we can obtain an alternative estimate of the impact of the program.

We start by running fixed effect models of grade progression in financial literacy, defined as the difference between grades in the pre- and the post-test. All models use the subset of students in treated schools in Madrid, but, unlike previous tables, the sample also includes students of treated schools in 10th grade (who did not take the course). The dependent variable is the student-level change in the performance in the financial literacy test between the pre- and the post- test. The key independent variable takes value 1 if the student belongs to a class that received the financial literacy course and 0 otherwise. Finally, the model includes school-specific fixed effects.

The results are shown in Panel A of Table 8. Relative to their fourth-grade peers, third graders increased their financial score by $23 \%$ of one standard deviation between the pre- and the post- test. The estimate is rather similar when we include indicators of parental educational attainment or labor market status to account for within-school variation in parental background.

Next, we provide some support in favor of the identifying assumption (3) by comparing the evolution of grades in financial literacy among 10th graders in treated schools to 9th graders in control schools. The idea is that neither group has received a course in financial literacy so, if the acquisition of financial knowledge differed between younger and older students, one should expect differences in the rate of growth of performance in financial literacy tests to differ. The panel B of Table 8 regresses the change in the financial score on a dummy of fourth year of high school using the full sample of control students in Madrid. The coefficient of fourth grade is $8 \%$ of one standard deviation, small and statistically not different from zero. In sum, the evidence from fixed-effect models supports the notion that training in financial literacy increases performance in financial competences. Hence, the evolution of financial knowledge, as measured by tests, does not seem to depend on the students' age.

Finally, columns 2-4 in Table 8 present separate impacts by topic of the exam. Again, the largest impacts are observed in banking relationships. However, in this sample we do not observe a gain in the savings and financial planning questions. The differences across topics may be due to the specific sample of six schools, though.

In sum, the change in mean scores in financial knowledge exams is about $23 \%$ of one standard deviation larger among treated students than among control students in the same school. The student-school fixed effects estimates are hence similar to those presented previously. 


\section{Selection Bias}

The estimates in the previous section can be challenged on the grounds that treated schools volunteer for the program, while control schools did not. Hence, students in treated schools may have unobserved characteristics that correlate with the decision of the principals to participate in financial literacy programs and with financial competence. This Section uses PISA data on financial literacy to characterize possible selection biases in a context in which we know that the true effect of a non-existent program is zero.

We start by defining selection bias in our context, following Heckman et al. (1998). Let's consider the following linear model:

$$
Y_{t}=X_{t}^{\prime} \beta+Z_{t}^{\prime} \gamma+\epsilon_{t}
$$

which through a regression analysis compares the average results of PISA students in moment $t$ $\left(Y_{t}\right)$ according to such observables as characteristics of the school $\left(X_{t}\right)$ and family environment $\left(Z_{t}\right)$. Let us now consider that one of the characteristics of the school is the availability of FE in the academic curriculum, indicating as $E\left(Y_{t} \mid \cdot\right)$ the conditioned average of the $Y$ variable at a concrete value of the regressors. We would then have:

$$
E\left(Y_{t} \mid X_{t}=x, Z_{t}=z, E F_{t}=e f\right)=x^{\prime} \beta+z^{\prime} \gamma+\delta e f .
$$

This regression provides us with descriptive information about the statistical association between receiving financial literacy courses and the performance in a standardized test. However, it is hard to attach a causal interpretation to the estimated coefficients due to possible selection biases that arise because of the influence of unobservable variables on both the decision to offer the FE courses and the financial performance of the students. It is difficult to establish a priori the sign or magnitude of such bias.

Suppose we replicate the analysis in (4) by substituting $E F$ for an indicator $D_{t+1}$ if the school volunteered for the BdE-CNMV Program without having any FE course available in the school before, then ${ }^{21}$ :

$$
E\left(Y_{t} \mid X_{t}=x, Z_{t}=z, D_{t+1}=1\right)=x^{\prime} \beta+z^{\prime} \gamma+\alpha D
$$

In the absence of selection bias, the estimated $\alpha$ should be zero. Otherwise, the size of the coefficient will provide us with a measure of how important the selection bias is and for which population groups it is most relevant. ${ }^{22}$ Given the previous analysis, we use the inverse

\footnotetext{
${ }^{21} D_{t+1}$ is measured in moment $t+1$ and scores $Y_{t}$ in moment $t$ because the treatment will happen in one after financial knowledge is measured in PISA.

${ }^{22}$ The PISA test on financial capabilities took place in the second semester of 2012, before the students were able to participate in the BdE-CNMV program. It is, therefore, possible that the performance on PISA financial tests could cause schools to be more sensitive to the need to offer FE in their schools. However, among the reasons that the schools indicated for their enrollment in the program, none mentioned the results PISA financial literacy test.
} 
probability weighting estimator described in Section 3 to assess if estimators that control for differences in observable variables eliminate biases due to unobservable variables.

Thus, the first step consists in estimating the adjusted probability of volunteering for the program depending on a series of characteristics, $V=\{X, Z\}$, in which "treated" and "control" students differ. The second step involves weighting the students in the control group in such a way that their observable weighted characteristics coincide with those of the treated group. In the third step, the (nonexistent) effect of participating in the BdE-CNMV program for the "treated" students - or selection bias $(B)$ - is constructed as the difference between the average outcomes of "treated" students and weighted average outcomes of the "control" group - weighted with the $\widehat{\omega(V)} \equiv \hat{\omega}$ weights:

$$
B(V)=E\left(Y_{t} \mid D_{t+1}=1\right)-E\left(\hat{\omega} Y_{t} \mid D_{t+1}=0\right)
$$

$B(V)$ can be estimated via a linear regression model where the treated observations receive a weight of 1 and the controlled ones the weight $\hat{\omega}$. If the model is well specified, the estimate of $B(\hat{\omega})$ should not vary if the regression also includes the characteristics vector $V$ as additional regressors. Selection bias $B(V)$ will disappear, therefore, if, for a given $V$, the average performance of the "treated" group does not differ significantly from that of the reweighted average of the "controls". 23

\subsection{The data}

Throughout the exercise, we make use of two different samples (see Table 9):

(1) Students who took the PISA financial literacy test in schools that do not offer Financial Education (Sample 1) Our main sample is made up of 919 students from 151 schools in Spain that do not offer nor have offered financial education. In each of these schools around 8 students took the PISA financial literacy test. In turn, the sample is made up of 119 "treated" students - students in schools that volunteered for the BdE-CNMV program in 2013 and/or 2014 - and 800 "control" students - students from schools that did not volunteer for this program. ${ }^{24}$ This first sample, therefore, allows for characterizing the differences in financial literacy among students from schools that volunteered for the program and those in schools that did not. The difference in financial literacy scores cannot be due to literacy acquired in a course offered at least one year later, but rather to the influence of other factors (unobserved) that explain the decision to participate in a program of this kind. In a second instance, the analysis

\footnotetext{
${ }^{23}$ PISA gives five possible values of literacy outcomes to each student that responds to that part of the questionnaire. For the purpose of this study, the first out of the 5 possible values allocated for the test is used. Furthermore, the standard errors presented do not use replication weights. Future versions of the study will examine the robustness of the results to the consideration of these two issues.

${ }^{24}$ We are not aware of the existence of any other FE program in which these schools could have participated after 2012 .
} 
of this sample also permits identifying which variables account for the selection bias. Although the sample size is limited, we still consider that it is large enough to deliver informative results. For example, Heckman et al. (1998) use samples of about 200 treated subjects to investigate the properties of selection biases in employment programs.

(2) Students who took the PISA financial literacy test and students who took other PISA tests in the schools from sample 1 (Sample 2) The relatively small sample size per school in sample 1 complicates inferences about the characteristics of the student body of the school on the basis of the group of students that take the PISA financial exam. For this reason, we have created an additional sample that links total PISA information (with 4 times more students per school) with sample 1. While this sample lacks information about performance on financial knowledge for all students, it enables examining other student outcomes, in a more reliable way, such as rate of repetition or the results in math and reading tests.

\subsection{Are the schools that volunteered for the BdE-CNMV program different from the rest?}

Differences in sample 1 Table 10 compares the characteristics of the students in sample 1. In comparing schools that volunteered and not, we focus on three types of factors. First, we examine the geographical location as well as the institutional form of the school -public or private. Secondly, and given the possible differences in admissions criteria, we examine the student body selection practices, according to the school administration. Finally, we look at both the family environment and some performance measures - for example, if the student has been held back a year. The schools that later showed an interest in participating in the BdECNMV program in 2013 or 2014 differ from the rest of the institutions that did not teach the subject in all the mentioned factors. The most striking difference corresponds to geographic distribution: $62 \%$ of students in schools that applied to offer the program in 2013 or 2014 are located in Andalusia, Ceuta, Melilla, Murcia and the Canary Islands (we refer to this group of regions as "South"). Conversely, among the schools that did not volunteer for the program, the percentage of students in the South is only $24 \%$. Secondly, around $43 \%$ of the students in the schools that asked to offer the program were private or state subsidized, while among the institutions that did not request to participate in the program, the proportion of private or state-subsidized institutions was $32 \%$. Finally, for the schools that participated in the program in 2013 or 2014, the proportion of students held back is 7 percentage points lower than among the rest of schools. The information that the school administration provides illustrates two possible reasons for the lower repetition rate in participating schools in the BdE-CNMV program. The applicant schools are exposed to greater competition with other schools in the district and use different admissions criteria: $41 \%$ never select their students based on the student's residence 
criterion, while in the rest of the schools this percentage is only $19 \% .{ }^{25}$ Secondly, $33 \%$ of the treated students attend schools that can transfer students with behavior problems to other schools, while the percentage in the rest of the institutions is $25 \%$. Regarding the average grade on the financial test, students from the volunteer schools and in the rest obtained rather similar scores (around 480 points in both cases). The lack of differences suggests that there is no selection bias among the schools that would later participate in the BdE-CNMV program. Despite of the large differences in school type, location and school admission procedures, the degree of financial literacy of the student body was, at first glance, similar to that of the other schools.

Differences by gender The absence of differences in performance on PISA financial among schools that volunteered and schools that didn't obscures substantial differences in the performance between boys and girls: treated girls perform substantially worse than girls in the control group; in particular, their financial literacy grades are one quarter of one standard deviation below girls in non-participant schools (see Table 11). The negative difference in PISA performance between treated girls and girls from the control group is compensated by a positive difference for the treated boys, whose performance on the exam improves that of the boys from the control group by, again, one quarter of one standard deviation.

To study to what extent these gender differences persist in larger samples of students of those schools, we briefly examine three alternative measures of the performance of the students in a bigger sample.

Differences in sample 2 Table 12 shows the characteristics of the student body in the linked sample with the total PISA sample - with a size 4 times greater than our main sample. Obviously, the linked sample does not allow for comparing the performance of the students on financial PISA, but it does provide other indications of the students' performance, such as the proportion of students being held back and the scores on PISA math and reading tests.

The results shown in Table 12 suggest that part of the differences in student performance observed on PISA financial can be attributed to a small sample size. For example, the rate of treated males repeating a grade is $25 \%$ in sample 1 , an abnormally low percentage compared with that observed for these same schools in sample 2 (where it is $32 \%$ ). The average performance of boys on the math test is 473 in the treated schools, a slightly inferior figure than that of the rest of the schools, where it is $485 .{ }^{26}$

\footnotetext{
${ }^{25}$ Public schools and state-subsidized schools have an assigned area of influence in which residents are given preference for entering the school, while private schools do not have this preference. Still, some public or statesubsidized schools indicate having the capability of selecting their students regardless of their place of residence.

${ }^{26}$ While differences exist among the schools in PISA results on reading and math exams, we found that these play less of a role when it comes to understanding selection bias on financial scores and are not considered in the remainder of the analysis.
} 
For its part, the rate of grade repetition among "treated" girls is substantially lower in treated schools than in control schools. As for scores on PISA - math and reading - the performance of "treated" girls is very similar to that of the control schools, the substantially lower rate of repetition notwithstanding.

Summary: differences in treated and control schools The student body of the schools that volunteered for the BdE-CNMV program differ from the rest of schools along the following dimensions:

- In treated schools, prior to the implementation of the program, boys received substantially better scores on PISA financial literacy than those of the rest of the schools - their scores were one fourth of one standard deviation higher than among other schools. On the contrary, girls obtained substantially worse scores, the magnitude of the difference being again one fourth of one standard deviation.

- These discrepancies in financial literacy are partly explained by the small number of students who, in each school, took the PISA financial test. Among the boys who, in the treated schools, took the exam, an unusually low number had been held back a grade. However, that cannot be the whole story. The percentage of students that repeated a grade among treated girls was only slightly higher than the percentage that would be obtained in bigger samples.

- Finally, additional information suggests that the student body of the applicant schools differs systematically from the rest of the schools on account of factors beyond a possible limited size of the PISA financial sample. The administration of the treated schools claims to use selection criteria for their entire student body that differ from those applied by the other schools.

The existence of differences prior to the implementation of the BdE-CNMV program illustrates the difficulty of assessing the impact of FE courses on the students' level of financial literacy. The differences in performance in financial literacy between both groups of schools could reflect the influence of FE courses, but also, as Tables 11 and 12 reveal, that of other variables.

In this case, we know that PISA financial took place in 2012, before the BdE-CNMV program was implemented. Thus, the difference in financial literacy can only be due to the influence of unobserved characteristics or selection bias. The remainder of the paper examines which estimation procedures might eliminate the influence of selection bias in the relation between $\mathrm{FE}$ courses and financial literacy.

\subsection{Estimates of the selection bias}

The estimation of the selection bias involves three steps. The first consists of predicting the variable "request to teach Financial Education in the third year of secondary education", de- 
pending on the characteristics observed for students within each type of school. Secondly, that prediction is used to construct a weighted average for students in the control group. Finally, the average financial literacy of "treated" students is compared with the weighted average of students from the "control group" .

\subsubsection{First step: probability of participation in the program}

Two sets of information are used. First, a limited set of observed variables is used, which is usually available in other studies: geographical location of the school, student's gender, parents' employment status and whether the student has been held back (model 1). Given the evidence in Table 11, interactions of each of these variables with the student's gender are included. The second information set uses to a greater extent the information provided by school administrators by adding, among other factors, the selection criteria reported by the principal of the school (model 2).

The analysis of participation determinants confirms that the group of treated students contains fewer girls and more schools in regions of the South (see Table 13). Similarly, the sample of treated students contains an unusually high proportion of boys that have not repeated a grade and, to a lesser extent, of girls whose parents were employed at the time of the interview.

The analysis based on the limited information set (model 1) suggests that the students in the control group that study in regions of the South and, in the case of boys, those who have not repeated any grade are the ones most comparable to the treated students. Column 3 of Table 10 shows the average characteristics of the sample of control students once it is weighted according to the adjusted probability of participation with the smaller information set. It can be seen that the control sample, once weighted, is similar to that of the treated group in terms of rate of grade repetition and geographical composition.

\subsubsection{Second step: distribution of the predicted probability of participation}

Figure 5 shows the distributions of the predicted probability of participation -or propensity score- in the BdE-CNMV program for the treated groups (solid line) and control groups (dotted line). Results for model 1 suggest that both distributions, while very different in form, have values in a restricted set of values between 0 and 0.4 , with scarce concentration in zero. These properties suggest that the samples are comparable once weighted. ${ }^{27}$ For model 2, on the contrary, the support - although also common - is more sparse.

\subsubsection{Third step: selection bias}

Model 1: selection bias due to family environment, geographical location and repetition We now turn to a comparison between the average financial performance of the

\footnotetext{
${ }^{27} \mathrm{~A}$ concentration of predicted values of participation probability at around zero or one would indicate that for certain treated students, there are no comparable control students. It does not appear to be a relevant problem in this basic specification.
} 
"treated" group and that of the "control" sample -once reweighted to match the grade repetition rate, geographic location and family environment of treated students (see Table 14). The difference in the average score between the treated and control groups is substantially reduced when the control sample is reweighted. In particular, the difference between performance on PISA of students from schools that volunteered for the program and those that did not is reduced by approximately one third (the selection bias is reduced from $23 \%$ of one standard deviation to 16\%). Intuitively, the reason for the lower selection bias is that, when the results on PISA financial of non-repeater boys in the control group - whose performance is foreseeably better than that of the average - are more weighted, the positive difference between the result of treated and control students is reduced.

On the other hand, the difference between the performance of girls in participating schools in the BdE-CNMV program and the rest of the institutions is also reduced by half once we reweight the control sample by the fraction of repeaters, location or labor status of the family: the bias diminishes from $27 \%$ of one standard deviation to $13 \% .^{28}$

Nevertheless, the selection bias, while significantly smaller, does not disappear. ${ }^{29}$ One reason is that, after the control sample is re-weighted so that the average rate of repetition, geographic location and family environment are similar to those of the treatment group, control students continue differing from the treated in the capacity of their schools to select students (see the third column in Table 10). Indeed, the proportion of students in schools that select according to criteria other than residence is 20 points higher among treated than among weighted controls. Not only that, the difference in student selection capacity between treated and weighted control groups is very similar to the one relative to the unweighted control sample.

Next, the "control" sample is weighted to also coincide with the sample of "treated" students in the selection criteria of the school.

Model 2: selection bias due to family environment, geographic location, repetition and admissions criteria in the school The differences in admission criteria among the schools suggest an extension of the set of determinants of the variable "participation in the BdE-CNMV program" . In this second specification we include variables that reflect the type of school: if it is a religious school, two variables that indicate the selection criteria of the student body, and a variable that normally is not observable such as "teacher morale" according to the schools" principals. The variable "religious school" is included because the BdE-CNMV

\footnotetext{
${ }^{28}$ It should be noted that the coefficient of the variable "the school volunteers for the BdE-CNMV program" is similar in Column 2 of Table 14 (a regression of the performance on PISA regarding this single variable, weighted according to $\hat{\omega}$ weights) and in Column 3 of the same Table (a regression of the performance on PISA financial regarding the participation indicator and, in addition, all the regressors shown in Table 13, also weighted according to $\hat{\omega}$ weights). The robustness of the results suggest that the specification of the model that predicts participation is appropriate.

${ }^{29}$ For example, the confidence interval of $95 \%$ for the estimated bias for boys in Table 14, column 2, row 1 is $[-0.14,0.46]$, interval that contains the point estimate of the "true effect" of the program in Section 4.
} 
program was publicized widely among Catholic schools. The other variables are included for the purpose of comparing schools with similar admissions criteria. The fourth column in Table 10 shows that the samples of treated and control students, once weighted, are similar in all the aspects considered. Now, hovewer, the distribution of the probability of treatment for the control group has more variance and shows a certain accumulation in values close to zero (see the lower left panel in Figure 5).

In any case, after reweighting the sample according to model 2, the estimate of the selection bias drops to $9.8 \%$ of one standard deviation for girls and $7 \%$ for boys (see Table 14). In both cases, the magnitude of the selection bias is reduced by $65 \%$, dropping to an about a tenth of one standard deviation.

\subsubsection{Summary: selection bias in Secondary Education}

The results on PISA financial literacy of the schools that asked to participate in the BdE-CNMV program were very different from those of the rest of the schools one year before the program was implemented, suggesting that a significant selection bias exists. Between 33\% and 50\% of the size of this selection bias can be explained by differences in the geographic location of the schools, the employment status of students' father or a different rate of repetition of the students.

Moreover, the schools that asked to participate in Financial Education in the third year of Secondary Education also have student body admission criteria that differ from those of the rest of the schools. Accounting for these latter differences reduce the selection bias up to $65 \%$. The above results thus suggest that it is feasible to obtain estimates of the impact on PISA financial scores of receiving a course on FE with significantly reduced selection bias by re-weighting the sample according to basic observable variables.

\section{Conclusions}

A number of studies have analyzed if financial literacy training in high school has long lasting effects on financial decisions over the life cycle. Bernheim et al. (2001) documented that individuals who studied in US states that had in the curriculum financial education had accumulated higher wealth levels than the rest. Brown et al. (2013) find that individuals who underwent financial education are less likely to hold debt or hold lower debt-income ratios. Both studies suggest that the financial content of high school curriculum shapes portfolio decisions, presumably by increasing financial knowledge of the students. However, empirical studies on how specific financial literacy programs increase students' financial knowledge delivers mixed results (see Becchetti et al. 2011, or Lührmann et al. 2012). Those studies measure the evolution of financial knowledge by delivering the same questions before and after the course. Evidence from a large program in Brazil in Bruhn et al. (2013) yield stronger evidence, as the financial literacy course studied there increased financial literacy scores by $20 \%$ of one standard devia- 
tion, measured by different sets of questions delivered before and after the course. However, that course was unusually intensive: 78 hours spread over one year and a half. The change in the curriculum following such intervention is by no means trivial.

Our study examines the impact on financial knowledge of a financial literacy course given to 15 year olds in Spanish high schools in Madrid, the most densely populated region of Spain. The course consists of 10 modules of one hour each, which is relatively easy to integrate in Math, Social Sciences or other courses. We measure financial literacy by using tests similar to those implemented in PISA, the result of an interdisciplinary effort of pedagogues and economists. There are outcomes of interest other than performance in test scores. However, we consider that performance in tests is a key mediating outcome: it is hard to think that financial training may have long-run impacts on economic decisions if it does not even increase performance in general tests of financial knowledge.

We assess the impact of the program of Financial Literacy on tests by implementing reweighting estimators that construct counterfactuals for students in twenty schools that implemented the course using students from three schools that did not, but did conduct tests on financial knowledge. We document three results: (1) students of the course performed one third of one standard deviation better in a test of financial competences, being the impact positive over the whole distribution of financial knowledge; (2) students performed better in the subset of non-arithmetic questions, suggesting that the gain is not only due to practicing math; and, (3) gains in performance were mainly associated to questions on banking relationships and budgeting, as opposed to questions on sustainable consumption

Finally, our study provides an assessment of the extent of (and possible solutions to) the problem of selection bias. We do this using the 2012 PISA test on financial competence. We identify there the set of schools that take part of the BdE-CNMV program in 2013-2014 and investigate if their performance differs from that of the rest of the schools. As the financial literacy course only took place one year after the PISA exam, any difference in performance must be due to a selection bias. We document that there is indeed a selection bias, and that the re-weighting estimators that we use in the first part of the study go a long way in addressing that bias. Those results reassure us in using re-weighting estimators to study the impact of the program.

Our results are drawn from an urban sample in Madrid, and effects are likely different in other settings. In addition, the ultimate object of interest are financial decisions in adulthood. In further research, we expect to investigate those issues. 


\section{References}

[1] Alan, S. and S. Ertac. 2014. Good Things Come to Those Who (Are Taught How to) Wait: Results from a Randomized Educational Intervention on Time Preference. Unpublished manuscript, University of Essex.

[2] Ambuehl, S., D. Bernheim and A. Lusardi. 2014. Financial Literacy, Financial Competence, and Consumer Welfare. NBER Working Paper 20618.

[3] Alessie, R., M. Van Rooij, and A. Lusardi. 2011. Financial Literay, Retirement Preparation and Pension Expectations in the Netherlands. Journal of Pension Economics and Finance, 10 (4): $527-45$.

[4] Arrondel, L., M. Debbich, and F. Sauvignac. 2013. Financial Literacy and Financial Planning in France. Numeracy, 6 (2): article 8.

[5] Becchetti, L., S. Caiazza, and D. Coviello. 2011. Financial education and investment attitudes in high schools: evidence from a randomized experiment.CEIS Working Paper No. 210.

[6] Bernheim, D., D. Garrett, and D. Maki. 2001. Education and Saving: The Long-term Effects of High School Financial Curriculum Mandates. Journal of Public Economics 80: 435-565.

[7] Brown, M, W. van der Klaauw, J. Wen, and B. Zafar. 2013. Financial Education and the Debt Behavior of the Young. Federal Reserve Bank of New York, Staff report, Number 634.

[8] Bruhn, M., L. de Souza Leao, A. Legovini, R. Marchetti, and B. Zia. 2013. The Impact of High School Financial Education Experimental Evidence from Brazil. The World Bank Development Research Group \& Latin America and Caribbean Region. Policy Research Working Paper 6723.

[9] Bucher-Koenen, T., and A. Lusardi. 2011. Financial Literacy and Retirement Planning in Germany. Journal of Pension Economics and Finance, 10 (4): 565-84.

[10] Busso, M., J. DiNardo, and J. McCrary. 2013. New Evidence on the Finite Sample Properties of Propensity Score Matching and Reweighting Estimators. Review of Economics and Statistics, forthcoming.

[11] Chen, H., and R. P. Volpe. 1998. An Analysis of Personal Literacy among College Students. Financial Services Review, 7 (2): 253-266.

[12] Fornero, E. and C. Monticone. 2011. Financial Literacy and Pension Plan Participation in Italy. Journal of Pension Economics and Finance, 10 (4): 547-564.

[13] Heckman, J., H. Ichimura, J. Smith and P. Todd. 1998. Characterizing Selection Bias Using Experimental Data. Econometrica, 66(5): 1017-1098.

[14] Hirano, K., G. Imbens, and G. Ridder. 2003. Efficient Estimation of Average Treatment Effects Using the Estimated Propensity Score. Econometrica, 71(4): 1161-1189.

[15] Imbens, G. W. 2014. Matching Methods in Practice: Three Examples. IZA DP No. 8049. 
[16] Lührmann, M., M. Serra-Garcia, and J. Winter. 2012. The effects of financial literacy training: Evidence from a field experiment with German high-school children. Discussion Papers in Economics 14101, University of Munich, Department of Economics.

[17] Lührmann, M., M. Serra-Garcia, and J. Winter. 2014. The Impact of Financial Education on Adolescents' Intertemporal Choices. CESifo Working Paper Series 4925, CESifo Group Munich.

[18] Lusardi, A., and O. S. Mitchell. 2009. How Ordinary Consumers Make Complex Economic Decisions: Financial Literacy and Retirement Readiness. NBER Working Paper 15350.

[19] Lusardi, A. and O. S. Mitchell. 2011. Financial Literacy and Retirement Planning in the United States. Journal of Pension Economics and Finance 10(4): 509-525.

[20] Lusardi, A. and O. S. Mitchell. 2014. The Economic Importance of Financial Literacy: Theory and Evidence. Journal of Economic Literature, 52 (1): 5-44.

[21] Lusardi, A., O. S. Mitchell, and V. Curto. 2010. Financial Literacy Among the Young. Journal of Consumer Affairs, 44 (2): 358-380.

[22] Mandell, L. 2008. Financial Education in High School. In Overcoming the Saving Slump: How to Increase the Effectiveness of Financial Education and Saving Programs, Annamaria Lusardi Editor, Chicago and London: University of Chicago Press, 257-279.

[23] Organization for Economic Co-Operation and Development (OECD). 2005. Improving Financial Literacy: Analysis of Issues and Policies. Paris, France: OECD.

[24] Rosenbaum, P. and D. B. Rubin. 1983. The Central Role of the Propensity Score in Observational Studies for Causal Effects. Biometrika, 70 (1): 4155.

[25] Shim, S., B. L. Barber, N. A. Card, J. J. Xiao, and J. Serido. 2010. Financial Socialization of First-Year College Students: The Roles of Parents, Work, and Education. Journal of Youth and Adolescence, 33 (12): 1457-1470.

[26] Van Rooij, M., A. Lusardi, and R. Alessie. 2011. Financial Literacy and Stock Market Participation. Journal of Financial Economics 101(2): 449-472.

[27] Walstad, W., K. Rebeck, and R. MacDonald. 2010. The Effects of Financial Education on the Financial Knowledge of High School Students. Journal of Consumer Affairs 44(2): 336-357. 


\section{Tables and figures}

Table 1: Descriptive Statistics of 3rd grade ESO students in Madrid: treatment and control.

\begin{tabular}{lccc}
\hline \hline & Experimental & Control & Weighted control \\
\hline Number of schools* & 20 & 3 & \\
Number of students & 981 & 242 & \\
\multicolumn{1}{c}{ VARIABLES INCLUDED IN THE PROPENSITY SCORE } \\
\hline Girl & 0.495 & $\mathbf{0 . 2 7 7}$ & 0.521 \\
Grade repetition: & & & \\
- Yes & 0.120 & $\mathbf{0 . 1 8 2}$ & 0.131 \\
- Do not answer & 0.090 & $\mathbf{0 . 1 9 4}$ & 0.120 \\
Private school & 0.185 & $\mathbf{0 . 3 9 7}$ & 0.176 \\
Average rating on initial exam & 5.093 & 5.158 & 5.088 \\
Average rating on initial exam x Private school & 4.968 & $\mathbf{5 . 4 8 5}$ & 4.999 \\
Employment status of the mother: & & & \\
- Working & 0.647 & $\mathbf{0 . 4 8 3}$ & 0.649 \\
- Do not answer & 0.101 & $\mathbf{0 . 2 2 3}$ & 0.132 \\
Education of the mother: & & & \\
- Primary education & 0.040 & 0.041 & 0.027 \\
- Secondary education & 0.370 & $\mathbf{0 . 2 4 8}$ & 0.411 \\
- University middle grade & 0.238 & $\mathbf{0 . 1 6 5}$ & 0.240 \\
- University higher grade & 0.238 & $\mathbf{0 . 3 1 4}$ & $\mathbf{0 . 1 8 2}$ \\
- Do not answer & 0.113 & $\mathbf{0 . 2 3 1}$ & 0.140 \\
Occupation of the mother: & & & 0.271 \\
- High skilled & & $\mathbf{0 . 3 5 1}$ & 0.128 \\
- Middle skilled & & $\mathbf{0 . 2 4 8}$ & \\
- Low skilled & & 0.149 & $\mathbf{0 . 2 5 2}$ \\
- Do not answer & & & \\
\hline
\end{tabular}

\begin{tabular}{lccc}
\hline \multicolumn{4}{c}{ VARIABLES NOT INCLUDED IN THE PROPENSITY SCORE } \\
\hline Average rating on final exam & 5.239 & $\mathbf{4 . 7 3 8}$ & $\mathbf{4 . 8 8 2}$ \\
Employment status of the father: & & & \\
- Working & 0.780 & $\mathbf{0 . 6 8 2}$ & 0.749 \\
- Do not answer & 0.108 & $\mathbf{0 . 2 1 9}$ & 0.134 \\
Education of the father: & & \\
- Primary education & 0.045 & 0.041 & 0.040 \\
- Secondary education & 0.342 & $\mathbf{0 . 2 3 1}$ & 0.372 \\
- University middle grade & 0.203 & $\mathbf{0 . 1 2 4}$ & 0.165 \\
- University higher grade & 0.267 & $\mathbf{0 . 3 7 2}$ & 0.271 \\
- Do not answer & 0.143 & $\mathbf{0 . 2 3 1}$ & 0.152 \\
Occupation of the father: & & & \\
- High skilled & 0.359 & $\mathbf{0 . 4 3 4}$ & 0.345 \\
- Middle skilled & 0.312 & $\mathbf{0 . 1 4 0}$ & $\mathbf{0 . 2 4 6}$ \\
- Low skilled & 0.203 & 0.178 & 0.250 \\
- Do not answer & 0.126 & $\mathbf{0 . 2 4 8}$ & 0.159 \\
\hline Notes: ${ }^{*}$ In one school there were both experimental and control classes in 3rd grade ESO. Examination \\
results on a scale of 0 to 10. Bold characters indicate diference statistical significant at a 5 percent level.
\end{tabular}


Table 2: Implementation of the program, by type of school.

\begin{tabular}{lccc}
\hline \hline & All schools & Non-private schools & Private schools \\
\hline Female child & 0.49 & 0.52 & 0.37 \\
Child has repeated a grade & 0.13 & 0.14 & 0.06 \\
& & & \\
Mother works & 0.72 & 0.71 & 0.77 \\
Father works & 0.87 & 0.85 & 0.97 \\
Mother has a college degree & 0.54 & 0.48 & 0.83 \\
Father has a college degree & 0.55 & 0.48 & 0.86 \\
& & & \\
Completed at least 7 modules (out of 9) & 0.90 & 0.91 & 0.88 \\
Median hours & 10 & 12 & 10 \\
Years of experience in teaching & 17.24 & 16.07 & 21.75 \\
Used the Webpage & 0.80 & 0.85 & 0.63 \\
Made an evaluation & 0.43 & 0.55 & 0.00 \\
\hline Number of treated students & 981 & 799 & 182 \\
\hline \hline
\end{tabular}


Table 3: Logistic regression of the probability of belonging to the treated group.

\begin{tabular}{lcc}
\hline \hline & {$[1]$} & {$[2]$} \\
\hline Score on the pre-test & 0.0797 & 0.0812 \\
& $(0.0815)$ & $(0.0745)$ \\
Score on the pre-test x Private school & $-0.5117^{* * *}$ & $-0.4286^{* * *}$ \\
& $(0.1431)$ & $(0.1254)$ \\
Girl & $0.7503^{* * *}$ & $0.7343^{* * *}$ \\
& $(0.1700)$ & $(0.1696)$
\end{tabular}

Grade repetition:

- Yes

$$
\begin{array}{cc}
-0.9413^{* * *} & -0.9447^{* * *} \\
(0.2272) & (0.2277) \\
0.4010 & 0.3451 \\
(0.5947) & (0.5941) \\
1.775 * * & 2.0794^{* *} \\
(0.7731) & (0.8954)
\end{array}
$$

- Do not answer $\quad 0.4010 \quad 0.3451$

Private school

Employment status of the mother:

- Working

$$
\begin{array}{cc}
0.6251^{* * *} & 0.6337^{* * *} \\
(0.1919) & (0.1922) \\
-0.8113 & -0.8251^{*} \\
(0.4991) & (0.5004)
\end{array}
$$

- Do not answer

$-0.8113-0.8251^{*}$

Education of the mother:

- Secondary education

$$
\begin{array}{cc}
0.3188 & 0.3010 \\
(0.4041) & (0.4050) \\
0.2041 & 0.1871 \\
(0.4417) & (0.4430) \\
-0.1374 & -0.1767 \\
(0.4417) & (0.4541) \\
-0.0988 & -0.0877 \\
(0.5745) & (0.5769)
\end{array}
$$

- University middle grade

$0.2041 \quad 0.1871$

- University higher grade

- Do not answer

Occupation of the mother:

- High skilled

$\begin{array}{cc}0.0398 & 0.0470 \\ (0.3087) & (0.3090) \\ 0.6503^{* *} & 0.6395^{* *} \\ (0.2609) & (0.2610)\end{array}$

- Middle skilled

$0.2923 \quad 0.3082$

- Do not answer

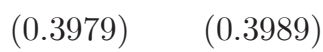

Constant

$0.4542 \quad 0.3263$

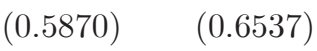

Number of observations

1,223

Notes: Examination results on a scale of 0 to 10. Column 1 uses normalized scores in the pre-test, while column 2 uses the average of correct answers. Standard errors in parentheses. ${ }^{* * *} 1,{ }^{* *} 5$, and $* 10$ percent significance level, respectively. 
Table 6: The effect of financial literacy courses on the post-test average of correct answers, by topic.

\begin{tabular}{lcccccc}
\hline \hline & Total score & Numeracy & $\begin{array}{c}\text { No } \\
\text { numeracy }\end{array}$ & $\begin{array}{c}\text { Saving and } \\
\text { planning }\end{array}$ & Banking & $\begin{array}{c}\text { Sustainable } \\
\text { Consumption }\end{array}$ \\
\hline Treatment - no c. & $0.4102^{*}$ & 0.2423 & $0.5073^{*}$ & $0.4207^{* *}$ & $0.4956^{*}$ & -0.1340 \\
& $(0.2406)$ & $(0.218)$ & $(0.2636)$ & $(0.1643)$ & $(0.2798)$ & $(0.5143)$ \\
Treatment - with c. & $0.3943^{* * *}$ & 0.2247 & $0.4925^{* * *}$ & $0.3957^{*}$ & $0.4842^{* * *}$ & -0.1493 \\
& $(0.1291)$ & $(0.1896)$ & $(0.1000)$ & $(0.2198)$ & $(0.1243)$ & $(0.1374)$ \\
\hline Mean of the scores & 6.91 & 7.09 & 6.81 & 7.04 & 6.72 & 7.67 \\
Sd of the scores & 1.43 & 1.69 & 1.55 & 1.79 & 1.60 & 2.88 \\
\hline Number of observations & & \multicolumn{5}{c}{1,223} \\
\hline
\end{tabular}

Notes: The table report estimates of an OLS regression of post-test average of correct answers on treatment. Control observations weighted by $\omega\left(X_{i}\right)=\frac{1-\pi}{\pi} \times \frac{e\left(X_{i}\right)}{1-e\left(X_{i}\right)}$, where $\pi=\operatorname{Pr}\left(D_{i}=1\right)$. Examination results on a scale of 0 to 10 . Robust standard errors, clustered at the school level, in parentheses. $* * * 1, * * 5$, and ${ }^{*} 10$ percent significance level, respectively. The covariates included in the logit are female, grade repetition, private school, pre-test, private school x pre-test, labor market status, education and occupation of the mother. Specifications Treatment-with c. also includes these covariates in the regression.

Table 7: The effect of financial literacy courses on post-test scores, by type of school.

\begin{tabular}{lcccc}
\hline \hline & \multicolumn{2}{c}{ Private schools } & \multicolumn{2}{c}{ Rest of schools } \\
\cline { 2 - 5 } & Normalized & Total & Normalized & Total \\
& score & score & score & score \\
\hline Treatment - no c. & -0.0390 & -0.1289 & $0.4517^{* * *}$ & $0.5375^{* * *}$ \\
& $(0.3824)$ & $(0.3787)$ & $(0.1434)$ & $(0.1427)$ \\
Treatment - with c. & -0.0551 & -0.1893 & $0.4400^{* * *}$ & $0.5266^{* * *}$ \\
& $(0.2416)$ & $(0.2493)$ & $(0.0617)$ & $(0.0650)$ \\
\hline Mean of the scores & 4.66 & 6.28 & 5.28 & 7.10 \\
Sd of the scores & 1.42 & 1.64 & 1.18 & 1.31 \\
\hline Number of observations & \multicolumn{3}{c}{278} \\
\hline \hline
\end{tabular}

Notes: The table report estimates of an OLS regression of post-test scores on treatment. Control observations weighted by $\omega\left(X_{i}\right)=\frac{1-\pi}{\pi} \times \frac{e\left(X_{i}\right)}{1-e\left(X_{i}\right)}$, where $\pi=\operatorname{Pr}\left(D_{i}=1\right)$. Examination results on a scale of 0 to 10 . Robust standard errors, clustered at the school level, in parentheses. $* * * 1, * * 5$, and $* 10$ percent significance level, respectively. The covariates included in the logit are female, grade repetition, private school, pre-test, private school $\mathrm{x}$ pre-test, labor market status, education and occupation of the mother. Specifications Treatment-with $c$. also includes these covariates in the regression. 
Table 8: Regressions of the change in the score between February and May.

\begin{tabular}{lcccc}
\hline \hline & $\begin{array}{c}\text { Change in the } \\
\text { score }\end{array}$ & $\begin{array}{c}\text { Saving and financial } \\
\text { planning }\end{array}$ & $\begin{array}{c}\text { Banking } \\
\text { relationships }\end{array}$ & $\begin{array}{c}\text { Sustainable } \\
\text { consumption }\end{array}$ \\
\hline Panel A: Within-school effects of FE on scores & & \\
\hline Treatment & $0.2746^{* *}$ & -0.0603 & $0.4187^{* * *}$ & 0.1919 \\
& $(0.1279)$ & $(0.3269)$ & $(0.0635)$ & $(0.1503)$ \\
\hline \multicolumn{5}{c}{1,409} \\
\hline Number of observations & 0.1132 & & \\
\hline Panel B: Effects of grade on score growth, control sample & 0.0359 & -0.0677 \\
4th grade of high-school & $(0.0767)$ & $(0.1678)$ & $(0.0967)$ & $(0.4609)$ \\
\hline Number of observations & \multicolumn{4}{c}{453} \\
\hline
\end{tabular}

Notes: Panel A reports school-fixed effect estimates of a regression of the change in the score between February and May on a dummy of treated students (controls are 4th year of high-school students in the same school). Panel B detects confounding age affects by regressing the change in the score between February and May on a 4th year of high-school dummy, using all controls (4th year high-school students in treated schools and 3rd year high-school students in control schools). Robust standard errors, clustered at the school level, in parentheses. $* * * 1, * * 5$, and $* 10$ percent significance level, respectively. Other covariates included are female, grade repetition, labor market status, education and occupation of both parents.

Table 9: Sample selection and sample sizes.

\begin{tabular}{lcc}
\hline \hline & Sample 1 & Sample 2 \\
\hline Number of schools & 151 & 151 \\
Number of students: & & \\
Total & 919 & 4,130 \\
Students in treated schools & 119 & 492 \\
Students in control schools & 800 & 3,638 \\
\hline \hline
\end{tabular}

Notes: in columns (1) and (2) treated schools are those that volunteered for the BdE-CNMV program in 2013 and/or 2014. Sample 1 includes students who took the PISA financial literacy test in schools that do not offer Financial Education; whereas sample 2 contains students who took the PISA financial literacy test and students who took other PISA tests in the schools from sample 1. 
Table 10: Differences between participants in the FE program and the rest of schools.

\begin{tabular}{|c|c|c|c|c|}
\hline & \multicolumn{2}{|c|}{ Weighted averages* } & \multicolumn{2}{|c|}{ Reweighted averages } \\
\hline & $\begin{array}{l}\text { Volunteer } \\
\text { schools }\end{array}$ & $\begin{array}{l}\text { Non-volunteer } \\
\text { schools }\end{array}$ & $\begin{array}{c}\text { Non-volunteer } \\
\text { schools } \\
\left(\text { model } 1^{* *}\right)\end{array}$ & $\begin{array}{c}\text { Non-volunteer } \\
\text { schools } \\
\left(\text { model } 2^{* * *}\right)\end{array}$ \\
\hline \multicolumn{5}{|c|}{ SCHOOL CHARACTERISTICS } \\
\hline Public school & 0.57 & 0.68 & 0.70 & 0.55 \\
\hline State-subsidized school & 0.18 & 0.13 & 0.13 & 0.10 \\
\hline Private school & 0.25 & 0.19 & 0.17 & 0.35 \\
\hline Religious school & 0.36 & 0.19 & 0.18 & 0.36 \\
\hline Does not admit students according to residence & 0.41 & 0.19 & 0.17 & 0.46 \\
\hline Transfers students to other schools for bad behavior & 0.33 & 0.25 & 0.27 & 0.32 \\
\hline Competes with at least one school in the area & 0.95 & 0.82 & 0.76 & 0.95 \\
\hline High teacher morale & 0.27 & 0.12 & 0.11 & 0.17 \\
\hline \multicolumn{5}{|c|}{ STUDENT CHARACTERISTICS } \\
\hline Average score on Financial Education & 482 & 484 & 481 & 482 \\
\hline Girl & 0.49 & 0.46 & 0.50 & 0.53 \\
\hline Has repeated grade & 0.27 & 0.34 & 0.27 & 0.25 \\
\hline Father works & 0.91 & 0.83 & 0.91 & 0.93 \\
\hline Father with college degree & 0.31 & 0.35 & 0.31 & 0.33 \\
\hline Mother works & 0.66 & 0.66 & 0.60 & 0.66 \\
\hline Mother with college degree & 0.36 & 0.36 & 0.33 & 0.31 \\
\hline \multicolumn{5}{|c|}{ CONTEXT CHARACTERISTICS } \\
\hline $\begin{array}{l}\text { South (Andalusia, Canary Islands, Ceuta and } \\
\text { Melilla, Murcia) }\end{array}$ & 0.62 & 0.24 & 0.62 & 0.60 \\
\hline Number of students & 119 & 800 & 800 & 800 \\
\hline
\end{tabular}

Notes: Sample 1. *Averages weighted by the sample weights. ** The column model 1 contains the averages of the control group when the sample is reweighted by the (inverse of the) probability of participation predicted by the location of the school, the father's work status, and the student's gender and rate of repetition.*** Model 2 contains the averages of the control group when the adjustment is made for the variables included in model 1 and, additionally, for the type of institution (public, state-subsidized or private), student body selection capacity, if the school competes with other schools in the area, teacher morale or if the school is religious. 
Table 11: Differences between participants in the FE program and the rest of schools (by gender).

\begin{tabular}{|c|c|c|c|c|}
\hline & \multicolumn{2}{|r|}{ Boys } & \multicolumn{2}{|c|}{ Girls } \\
\hline & $\begin{array}{l}\text { Volunteer } \\
\text { schools }\end{array}$ & $\begin{array}{l}\text { Non-volunteer } \\
\text { schools }\end{array}$ & $\begin{array}{l}\text { Volunteer } \\
\text { schools }\end{array}$ & $\begin{array}{l}\text { Non-volunteer } \\
\text { schools }\end{array}$ \\
\hline \multicolumn{5}{|c|}{ SCHOOL CHARACTERISTICS } \\
\hline Public school & 0.55 & 0.70 & 0.61 & 0.67 \\
\hline State-subsidized school & 0.22 & 0.12 & 0.13 & 0.14 \\
\hline Private school & 0.23 & 0.18 & 0.26 & 0.19 \\
\hline Does not admit students according to residence & 0.35 & 0.18 & 0.48 & 0.18 \\
\hline Transfers students to other schools for bad behavior & 0.35 & 0.28 & 0.30 & 0.20 \\
\hline Competes with at least one school in the area & 0.97 & 0.81 & 0.92 & 0.83 \\
\hline \multicolumn{5}{|c|}{ STUDENT CHARACTERISTICS } \\
\hline Average standardized score on Financial Education & 0.23 & 0.09 & -0.27 & -0.07 \\
\hline Has repeated grade & 0.25 & 0.40 & 0.28 & 0.27 \\
\hline \multicolumn{5}{|c|}{ CONTEXT CHARACTERISTICS } \\
\hline $\begin{array}{l}\text { South (Andalusia, Canary Islands, Ceuta and } \\
\text { Melilla, Murcia) }\end{array}$ & 0.58 & 0.25 & 0.65 & 0.22 \\
\hline Number of students & 63 & 428 & 56 & 372 \\
\hline
\end{tabular}

Notes: Sample 1. All averages weighted by the sample weights.

Table 12: Differences between participants in the FE program and the rest of schools (by gender).

\begin{tabular}{|c|c|c|c|c|}
\hline & \multicolumn{2}{|r|}{ Boys } & \multicolumn{2}{|c|}{ Girls } \\
\hline & $\begin{array}{l}\text { Volunteer } \\
\text { schools }\end{array}$ & $\begin{array}{l}\text { Non-volunteer } \\
\text { schools }\end{array}$ & $\begin{array}{l}\text { Volunteer } \\
\text { schools }\end{array}$ & $\begin{array}{l}\text { Non-volunteer } \\
\text { schools }\end{array}$ \\
\hline \multicolumn{5}{|c|}{ SCHOOL CHARACTERISTICS } \\
\hline Public school & 0.51 & 0.70 & 0.47 & 0.73 \\
\hline State-subsidized school & 0.21 & 0.13 & 0.23 & 0.12 \\
\hline Private school & 0.28 & 0.17 & 0.30 & 0.15 \\
\hline Does not admit students according to residence & 0.27 & 0.24 & 0.26 & 0.22 \\
\hline Transfers students to other schools for bad behavior & 0.40 & 0.17 & 0.48 & 0.18 \\
\hline Competes with at least one school in the area & 0.94 & 0.80 & 0.94 & 0.81 \\
\hline \multicolumn{5}{|c|}{ STUDENT CHARACTERISTICS } \\
\hline Average score on Maths & 473 & 485 & 476 & 467 \\
\hline Average score on Reading & 453 & 467 & 500 & 494 \\
\hline Has repeated grade & 0.34 & 0.37 & 0.23 & 0.32 \\
\hline \multicolumn{5}{|c|}{ CONTEXT CHARACTERISTICS } \\
\hline $\begin{array}{l}\text { South (Andalusia, Canary Islands, Ceuta and } \\
\text { Melilla, Murcia) }\end{array}$ & 0.82 & 0.32 & 0.74 & 0.33 \\
\hline Number of students & 251 & 1,832 & 241 & 1,806 \\
\hline
\end{tabular}

Notes: Sample 2. All averages weighted by the sample weights. 
Table 13: Determinants of the probability of participation in the FE program.

\begin{tabular}{|c|c|c|c|c|}
\hline & \multicolumn{2}{|c|}{ Model 1} & \multicolumn{2}{|c|}{ Model 2} \\
\hline & Coefficient & Robust SE & Coefficient & Robust SE \\
\hline \multicolumn{5}{|c|}{ STUDENT CHARACTERISTICS } \\
\hline Girl & $-1.851^{* *}$ & $(0.903)$ & -1.107 & $(1.030)$ \\
\hline Has repeated grade & -0.017 & $(0.516)$ & 0.075 & $(0.564)$ \\
\hline Has repeated grade $\times$ Girl & 0.845 & $(0.747)$ & 0.461 & $(0.813)$ \\
\hline Father works & -0.070 & $(0.503)$ & 0.360 & $(0.572)$ \\
\hline Missing father works & $1.437^{*}$ & $(0.808)$ & 1.657 & $(1.023)$ \\
\hline Father works $\times$ Girl & $1.791^{* *}$ & $(0.893)$ & 1.322 & $(0.994)$ \\
\hline Missing father works $\times$ Girl & 0.288 & $(1.243)$ & -0.183 & $(1.483)$ \\
\hline Mother works & & & 0.283 & $(0.308)$ \\
\hline Missing mother works & & & 0.887 & $(0.855)$ \\
\hline \multicolumn{5}{|c|}{ CONTEXT CHARACTERISTICS } \\
\hline South (Andalusia, Canary Islands, Ceuta and Melilla, Murcia) & $2.264^{* * *}$ & $(0.394)$ & $2.504^{* * *}$ & $(0.447)$ \\
\hline South $\times$ Girl & 0.077 & $(0.564)$ & 0.583 & $(0.644)$ \\
\hline South $\times$ Has repeated grade & $-1.759^{* *}$ & $(0.737)$ & $-1.939^{* *}$ & $(0.842)$ \\
\hline South $\times$ Has repeated grade $\times$ Girl & 0.424 & $(1.067)$ & 0.583 & $(1.188)$ \\
\hline \multicolumn{5}{|c|}{ SCHOOL CHARACTERISTICS } \\
\hline State-subsidized school & & & $-1.813^{* * *}$ & $(0.624)$ \\
\hline Private school & & & $-1.885^{* * *}$ & $(0.718)$ \\
\hline Religious school & & & $2.098^{* * *}$ & $(0.646)$ \\
\hline Does not admit students according to residence & & & $2.510^{* * *}$ & $(0.363)$ \\
\hline Does not admit students according to residence $\times$ South & & & -0.170 & $(0.675)$ \\
\hline Transfers students to other schools for bad behavior & & & $0.614^{* *}$ & $(0.300)$ \\
\hline Competes with at least one school in the area & & & $2.683^{* * *}$ & $(0.513)$ \\
\hline High teacher morale & & & $1.681^{* * *}$ & $(0.390)$ \\
\hline High teacher morale $\times$ Girl & & & $-1.569^{* * *}$ & $(0.587)$ \\
\hline Constant & $-2.812^{* * *}$ & $(0.494)$ & $-7.039 * * *$ & $(0.725)$ \\
\hline Pseudo R-squared & \multicolumn{2}{|c|}{0.145} & \multicolumn{2}{|c|}{0.305} \\
\hline Observations & \multicolumn{2}{|c|}{919} & \multicolumn{2}{|c|}{919} \\
\hline
\end{tabular}

Notes: Sample 1. The probability of participating in the program is estimated using a Logit model, weighting each observation by its population weight. Robust $\mathrm{SE}=$ robust standard error. $* * * 1$, **5, and $* 10$ percent significance level, respectively. 
Table 14: Differences in performance between participants in the FE program and the rest of schools.

\begin{tabular}{lccccc}
\hline \hline & \multirow{2}{*}{$\begin{array}{c}\text { Difference } \\
\text { treatment }\end{array}$} & \multicolumn{2}{c}{ Model 1 } & \multicolumn{2}{c}{ Model 2 } \\
\cline { 3 - 6 } & - control & covariates & With & W/o & With \\
& covariates & covariates & covariates \\
\hline \multirow{2}{*}{ FE program applicants: Boys } & $0.234^{*}$ & 0.164 & 0.167 & 0.142 & 0.073 \\
& $(0.144)$ & $(0.151)$ & $(0.138)$ & $(0.166)$ & $(0.148)$ \\
FE program applicants: Girls & $-0.274^{*}$ & -0.131 & -0.126 & -0.147 & -0.098 \\
& $(0.148)$ & $(0.160)$ & $(0.148)$ & $(0.169)$ & $(0.149)$ \\
\hline \hline
\end{tabular}

Notes: Sample 1. The table shows several estimates of the coefficient of the indicator that the school volunteered for the FE program in 2013-2014 and its standard error. ${ }^{* * *} 1$, ${ }^{*} 5$, and $* 10$ percent significance level, respectively. The dependent variable is the results on PISA financial, standardized in such a way that it has an average of 0 and standard deviation 1. A single imputed value is used. All the observations are weighted according to the sample weights provided in PISA. Estimation method: Ordinary Least Squares in Column 1, Weighted Least Squares by the inverse of the probability of participation (propensity score) in Columns 2-5. Model 1 contains indicators of gender and repetition, regional location and father's employment status. Model 2 adds to the above variables the type of school, whether the school admits students according to residence criteria and teacher characteristics.

Figure 1: Assessing the existence of common support.
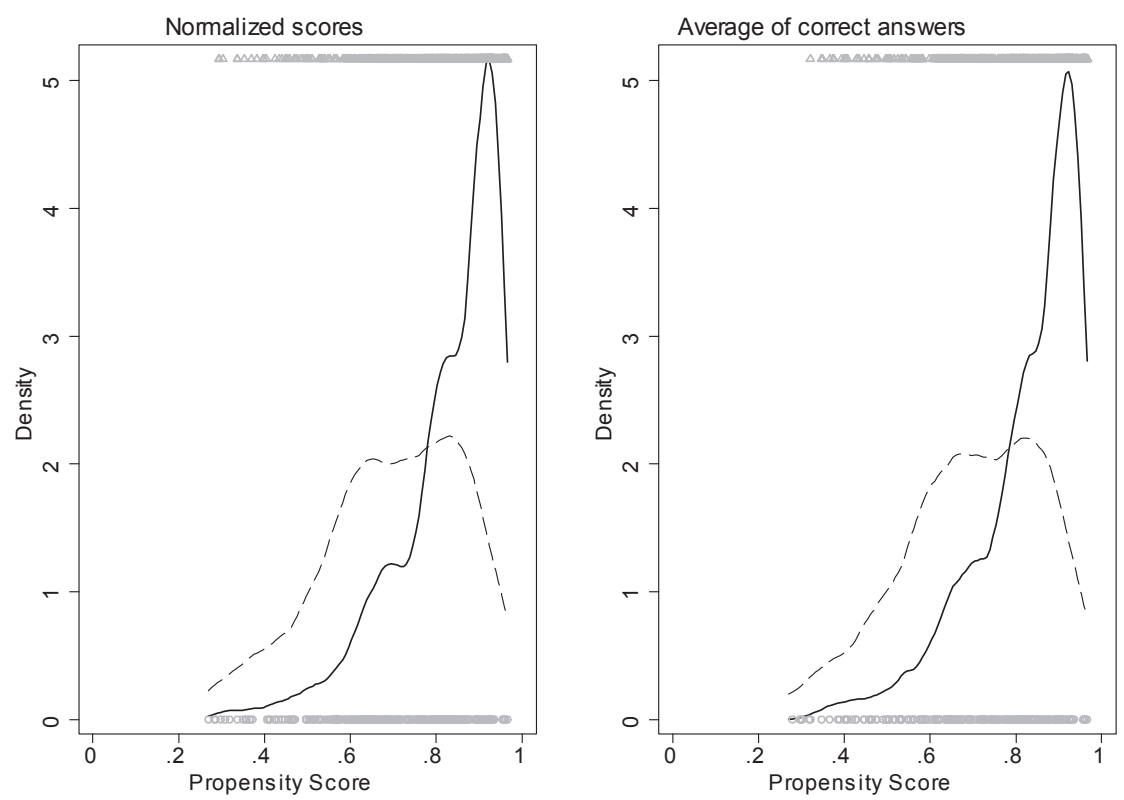

Notes: The solid lines represent the distribution of the predicted probabilities of treatment from the logit model for the treated, and the dashed lines for the controls. The covariates included in the logit are female, grade repetition, private school, pre-test, pre-test x private school, labor market status, education and occupation of the mother. See table 3 . 
Figure 2: Estimated cdf of the pre-test normalized scores.

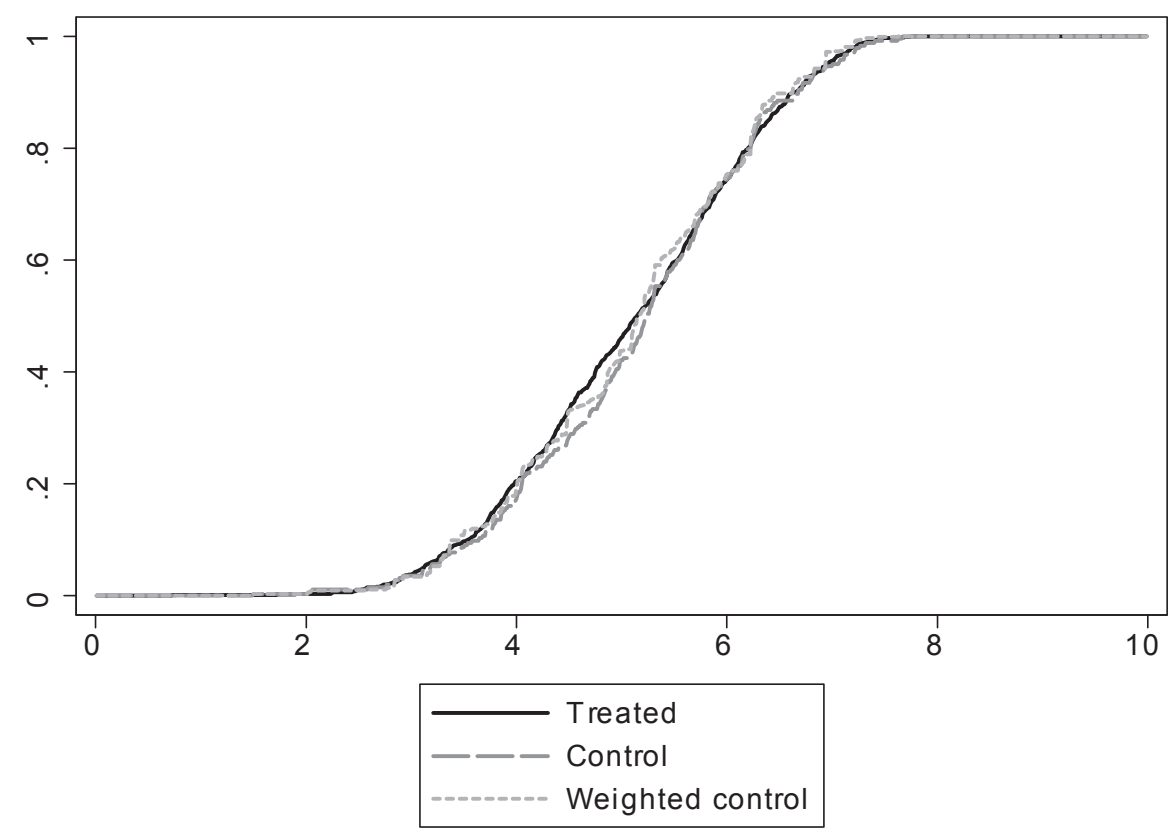

Notes: The control group is weighted by $\omega\left(X_{i}\right)=\frac{1-\pi}{\pi} \times \frac{e\left(X_{i}\right)}{1-e\left(X_{i}\right)}$, where $\pi=\operatorname{Pr}\left(D_{i}=1\right)$. The covariates included in the logit are female, grade repetition, private school, pre-test, pre-test x private school, labor market status, education and occupation of the mother. See table 3 . 
Figure 3: Estimated cdf of the post-test normalized scores.

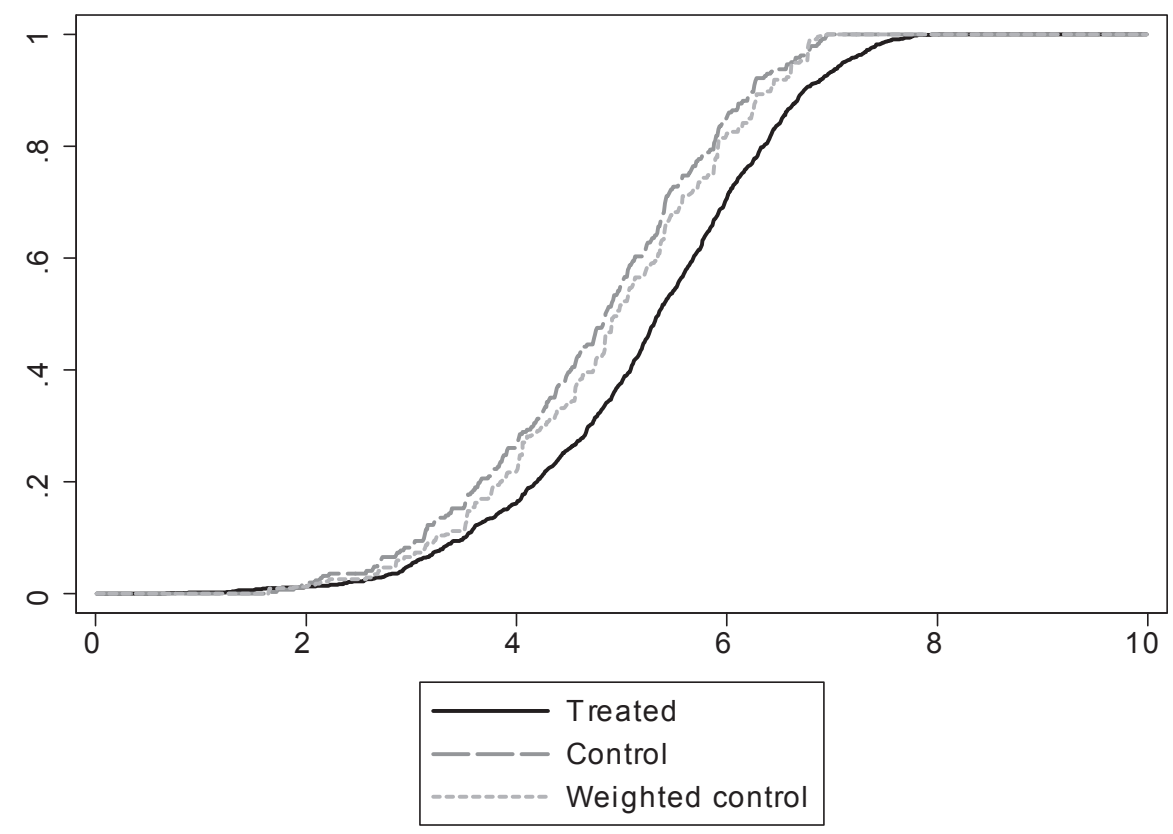

Notes: The control group is weighted by $\omega\left(X_{i}\right)=\frac{1-\pi}{\pi} \times \frac{e\left(X_{i}\right)}{1-e\left(X_{i}\right)}$, where $\pi=\operatorname{Pr}\left(D_{i}=1\right)$. The covariates included in the logit are female, grade repetition, private school, pre-test, pre-test x private school, labor market status, education and occupation of the mother. See table 3 . 
Figure 4: Assessing the existence of common support, by type of school.

\section{Private schools}
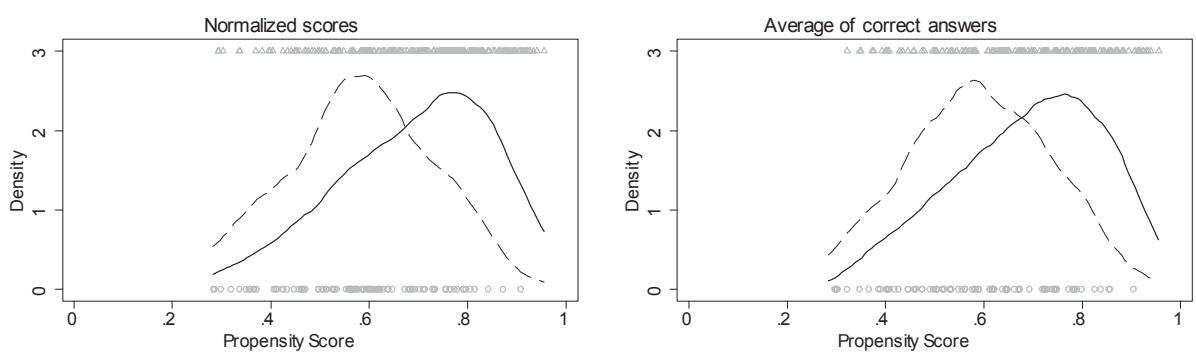

Non private schools
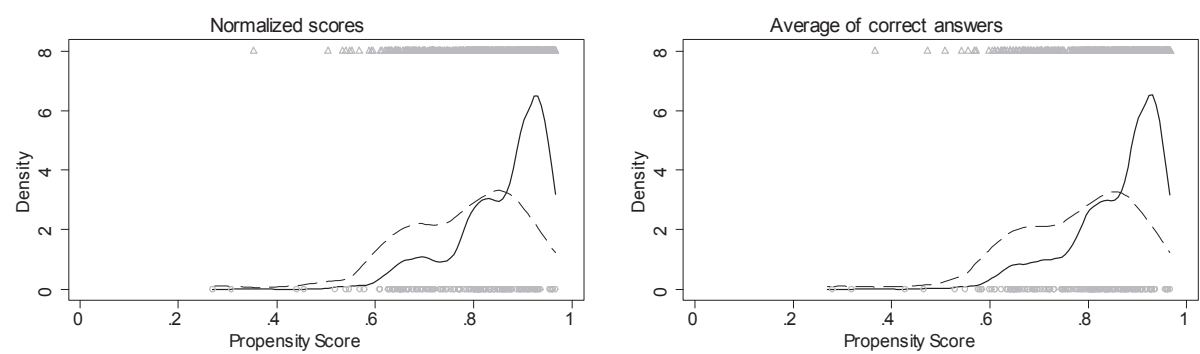

Notes: The solid lines represent the distribution of the predicted probabilities of treatment from the logit model for the treated, and the dashed lines for the controls. The covariates included in the logit are female, grade repetition, private school, pre-test, pre-test $\mathrm{x}$ private school, labor market status, education and occupation of the mother. See table 3 . 
Figure 5: Densities of predicted probabilities of participation in the BdE-CNMV program.
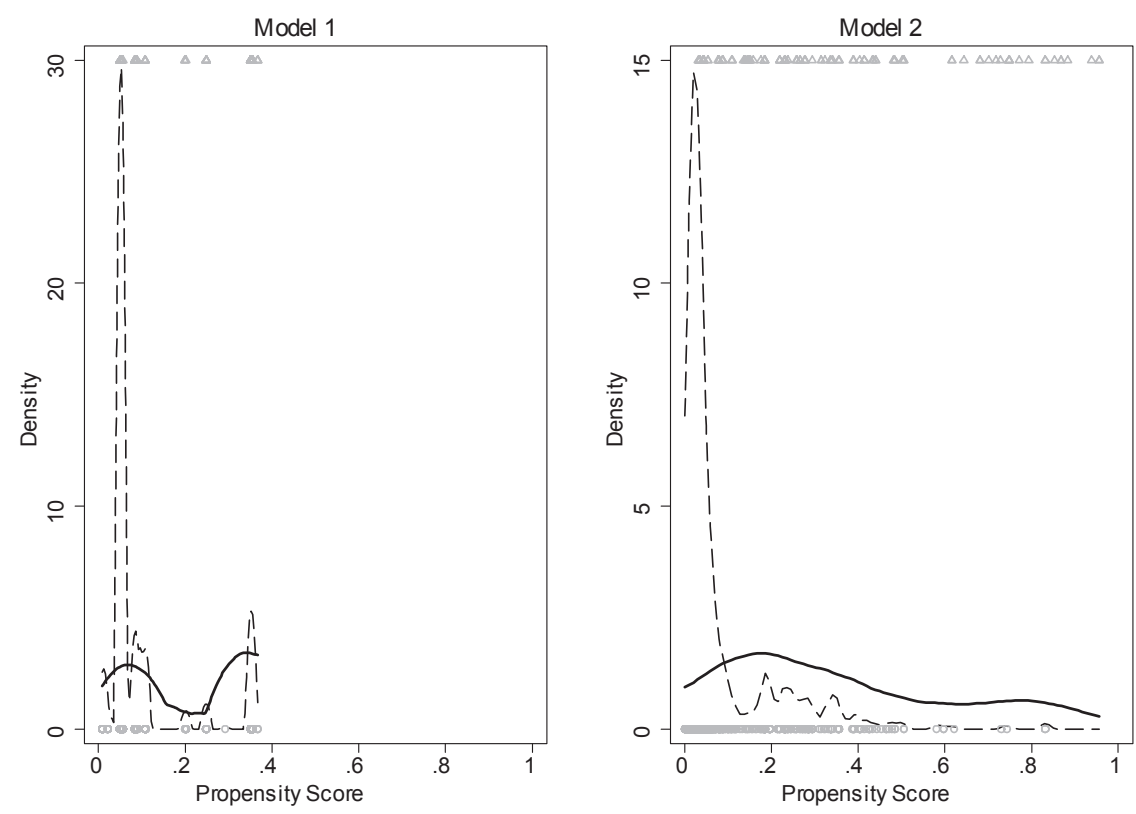

Notes: Sample 1. Density of probability of participation (propensity score) for treated (solid line) and control groups (dotted line). The circles on the X-axis show the probability of participation values for each student in the control group. The triangles represent the probability of participation for each student of the treated group. The left hand side graph corresponds to the propensity score computed using as covariates the geographic location if the school, student's gender, rate of repetition, father's employment status and interactions (columns 1 and 2 of Table 13). The graph in the right hand side corresponds to a propensity score that also includes the type of school, admission criteria and teacher characteristics (columns 3 and 4 of Table 13). 


\section{APPENDIX}

\section{A Topics covered in the program}

The financial literacy course taught in 2012-2013 was structured in nine chapters. There was a tenth one that reviewed the previous material.

Financial security Learning to manage money. Establishing savings goals and how to reach them.

Intelligent consumption How to improve quality of life by expenditure choices. The definition of healthy, responsible and sustainable consumption. The role of advertising.

Saving Definition of saving. Reasons for saving and the role of uncertainty. Differences between saving and investing.

Personal budgeting Elaboration of a personal budget. Identifying fixed and variable expenses. Identifying adjustable expenses.

Money and monetary transactions Advantages and disadvantages of using cash. Identification of fake currency.

Bank accounts Differences between checking and savings accounts. Opening a bank account. Consequences of an overdraft. Understanding checking account statements. Managing bank accounts. Internet and phone banking.

Credit and Debit Cards The use of credit and debit cards: advantages and disadvantages. The use of tellers and cash stations.

Data protection Problems using Internet banking.

Banking relationships Opening and closing bank accounts. Different forms of bank fees.

\section{B Contents of the tests}

Two different tests were passed in May 2013. Each student made only one, but to avoid leaking of information across classes and schools, not all students made the same test. We describe now the contents of the second one. The questions on the test spanned three main topics:

- Saving and Financial Planning (9 questions, 6 of them require an arithmetic computation)

- Money and Bank Accounts (18 questions, 5 of them require an arithmetic computation)

- Sustainable Consumption (3 questions, none of them requires an arithmetic computation) 
The questions on Saving and Financial planning presented students with data on hypothetical financial situations and asked about which concepts should be included in a budget or about how to reach specific targets given a flow of expected expenses and incomes. Questions on Money and Bank Accounts tried to establish if students understood the functioning of checking and savings account by means of specific examples. Those questions also presented situations where students had to identify the best payment methods for different outlays. Finally, students were tested about basic notions of security when using bank accounts. Questions about Sustainable consumption presented hypothetical situations where the students should to identify the most responsible expenditure pattern (i.e., the healthiest or the environmentally friendliest). 


\section{BANCO DE ESPAÑA PUBLICATIONS}

\section{WORKING PAPERS}

1301 JAMES COSTAIN and ANTON NAKOV: Logit price dynamics.

1302 MIGUEL GARCÍA-POSADA: Insolvency institutions and efficiency: the Spanish case.

1303 MIGUEL GARCÍA-POSADA and JUAN S. MORA-SANGUINETTI: Firm size and judicial efficacy: evidence for the new civil procedures in Spain.

1304 MAXIMO CAMACHO and GABRIEL PEREZ-QUIROS: Commodity prices and the business cycle in Latin America: living and dying by commodities?

1305 CARLOS PÉREZ MONTES: Estimation of regulatory credit risk models.

1306 FERNANDO LÓPEZ VICENTE: The effect of foreclosure regulation: evidence for the US mortgage market at state level.

1307 ENRIQUE MORAL-BENITO and LUIS SERVEN: Testing weak exogeneity in cointegrated panels.

1308 EMMA BERENGUER, RICARDO GIMENO and JUAN M. NAVE: Term structure estimation, liquidity-induced heteroskedasticity and the price of liquidity risk.

1309 PABLO HERNÁNDEZ DE COS and ENRIQUE MORAL-BENITO: Fiscal multipliers in turbulent times: the case of Spain.

1310 SAMUEL HURTADO: DSGE models and the Lucas critique.

1311 HENRIQUE S. BASSO and JAMES COSTAIN: Fiscal delegation in a monetary union with decentralized public spending

1312 MAITE BLÁZQUEZ CUESTA and SANTIAGO BUDRÍA: Does income deprivation affect people's mental well-being?

1313 ENRIQUE ALBEROLA, ÁNGEL ESTRADA and DANIEL SANTABÁRBARA: Growth beyond imbalances. Sustainable growth rates and output gap reassessment.

1314 CARMEN BROTO and GABRIEL PEREZ-QUIROS: Disentangling contagion among sovereign CDS spreads during the European debt crisis.

1315 MIGUEL GARCÍA-POSADA and JUAN S. MORA-SANGUINETTI: Are there alternatives to bankruptcy? A study of small business distress in Spain.

1316 ROBERTO RAMOS and ENRIQUE MORAL-BENITO: Agglomeration matters for trade.

1317 LAURA HOSPIDO and GEMA ZAMARRO: Retirement patterns of couples in Europe.

1318 MAXIMO CAMACHO, GABRIEL PEREZ-QUIROS and PILAR PONCELA: Short-term forecasting for empirical economists. A survey of the recently proposed algorithms.

1319 CARLOS PÉREZ MONTES: The impact of interbank and public debt markets on the competition for bank deposits.

1320 OLYMPIA BOVER, JOSE MARIA CASADO, SONIA COSTA, PHILIP DU CAJU, YVONNE MCCARTHY, EVA SIERMINSKA, PANAGIOTA TZAMOURANI, ERNESTO VILLANUEVA and TIBOR ZAVADIL: The distribution of debt across euro area countries: the role of Individual characteristics, institutions and credit conditions.

1321 BRINDUSA ANGHEL, SARA DE LA RICA and AITOR LACUESTA: Employment polarisation in Spain over the course of the 1997-2012 cycle.

1322 RODOLFO G. CAMPOS and ILIANA REGGIO: Measurement error in imputation procedures.

1323 PABLO BURRIEL and MARÍA ISABEL GARCÍA-BELMONTE: Meeting our DESTINY. A Disaggregated €uro area Short Term Indicator model to forecast GDP (Y) growth.

1401 TERESA SASTRE and FRANCESCA VIANI: Countries' safety and competitiveness, and the estimation of current account misalignments.

1402 FERNANDO BRONER, ALBERTO MARTIN, AITOR ERCE and JAUME VENTURA: Sovereign debt markets in turbulent times: creditor discrimination and crowding-out effects.

1403 JAVIER J. PÉREZ and ROCÍO PRIETO: The structure of sub-national public debt: liquidity vs credit risks.

1404 BING XU, ADRIAN VAN RIXTEL and MICHIEL VAN LEUVENSTEIJN: Measuring bank competition in China: a comparison of new versus conventional approaches applied to loan markets.

1405 MIGUEL GARCÍA-POSADA and JUAN S. MORA-SANGUINETTI: Entrepreneurship and enforcement institutions: disaggregated evidence for Spain.

1406 MARIYA HAKE, FERNANDO LÓPEZ-VICENTE and LUIS MOLINA: Do the drivers of loan dollarisation differ between CESEE and Latin America? A meta-analysis.

1407 JOSÉ MANUEL MONTERO and ALBERTO URTASUN: Price-cost mark-ups in the Spanish economy: a microeconomic perspective.

1408 FRANCISCO DE CASTRO, FRANCISCO MARTÍ, ANTONIO MONTESINOS, JAVIER J. PÉREZ and A. JESÚS SÁNCHEZ-FUENTES: Fiscal policies in Spain: main stylised facts revisited. 
1409 MARÍA J. NIETO: Third-country relations in the Directive establishing a framework for the recovery and resolution of credit institutions.

1410 ÓSCAR ARCE and SERGIO MAYORDOMO: Short-sale constraints and financial stability: evidence from the Spanish market.

1411 RODOLFO G. CAMPOS and ILIANA REGGIO: Consumption in the shadow of unemployment.

1412 PAUL EHLING and DAVID HAUSHALTER: When does cash matter? Evidence for private firms.

1413 PAUL EHLING and CHRISTIAN HEYERDAHL-LARSEN: Correlations.

1414 IRINA BALTEANU and AITOR ERCE: Banking crises and sovereign defaults in emerging markets: exploring the links.

1415 ÁNGEL ESTRADA, DANIEL GARROTE, EVA VALDEOLIVAS and JAVIER VALLÉS: Household debt and uncertainty: private consumption after the Great Recession.

1416 DIEGO J. PEDREGAL, JAVIER J. PÉREZ and A. JESÚS SÁNCHEZ-FUENTES: A toolkit to strengthen government budget surveillance.

1417 J. IGNACIO CONDE-RUIZ, and CLARA I. GONZÁLEZ: From Bismarck to Beveridge: the other pension reform in Spain.

1418 PABLO HERNÁNDEZ DE COS, GERRIT B. KOESTER, ENRIQUE MORAL-BENITO and CHRISTIANE NICKEL: Signalling fiscal stress in the euro area: a country-specific early warning system.

1419 MIGUEL ALMUNIA and DAVID LÓPEZ-RODRÍGUEZ: Heterogeneous responses to effective tax enforcement: evidence from Spanish firms.

1420 ALFONSO R. SÁNCHEZ: The automatic adjustment of pension expenditures in Spain: an evaluation of the 2013 pension reform.

1421 JAVIER ANDRÉS, ÓSCAR ARCE and CARLOS THOMAS: Structural reforms in a debt overhang.

1422 LAURA HOSPIDO and ENRIQUE MORAL-BENITO: The public sector wage premium in Spain: evidence from longitudinal administrative data.

1423 MARÍA DOLORES GADEA-RIVAS, ANA GÓMEZ-LOSCOS and GABRIEL PÉREZ-QUIRÓS: The Two Greatest. Great Recession vs. Great Moderation.

1424 ENRIQUE MORAL-BENITO and OLIVER ROEHN: The impact of financial (de)regulation on current account balances

1425 MÁXIMO CAMACHO and JAIME MARTÍNEZ-MARTÍN: Real-time forecasting US GDP from small-scale factor models.

1426 ALFREDO MARTÍN OLIVER, SONIA RUANO PARDO and VICENTE SALAS FUMÁS: Productivity and welfare: an application to the Spanish banking industry.

1427 JAVIER ANDRÉS and PABLO BURRIEL: Inflation dynamics in a model with firm entry and (some) heterogeneity.

1428 CARMEN BROTO and LUIS MOLINA: Sovereign ratings and their asymmetric response to fundamentals.

1429 JUAN ÁNGEL GARCÍA and RICARDO GIMENO: Flight-to-liquidity flows in the euro area sovereign debt crisis.

1430 ANDRE LEMELIN, FERNANDO RUBIERA-MOROLLÓN and ANA GÓMEZ-LOSCOS: Measuring urban agglomeration. A refoundation of the mean city-population size index.

1431 LUIS DÍEZ-CATALÁN and ERNESTO VILLANUEVA: Contract staggering and unemployment during the Great Recession: evidence from Spain.

1501 LAURA HOSPIDO and EVA MORENO-GALBIS: The Spanish productivity puzzle in the Great Recession.

1502 LAURA HOSPIDO, ERNESTO VILLANUEVA and GEMA ZAMARRO: Finance for all: the impact of financial literacy training in compulsory secondary education in Spain.

BANCODEESPAÑA Eurosistema
Unidad de Servicios Auxiliares

Alcalá, 48 - 28014 Madrid

E-mail: publicaciones@bde.es www.bde.es 